\title{
Synthesis, characterization and cytotoxic properties of platinum(II) complexes containing the nucleosides adenosine and cytidine ${ }^{\text {is }}$
}

\author{
Diego Montagner ${ }^{\mathrm{a}}$, Valentina Gandin ${ }^{\mathrm{b}}$, Cristina Marzano ${ }^{\mathrm{b}}$, Bruno Longato ${ }^{\mathrm{a}, *}$ \\ a Dipartimento di Scienze Chimiche, Università di Padova, Via Marzolo 1, 35131-Padova, Italy \\ ${ }^{\mathrm{b}}$ Dipartimento di Scienze Farmaceutiche, Università di Padova, Via Marzolo 5, 35131-Padova, Italy
}

\section{A R T I C L E I N F O}

\section{Article history:}

Received 22 December 2010

Received in revised form 15 March 2011

Accepted 15 March 2011

Available online 23 March 2011

\section{Keywords:}

Nucleosides complexes of platinum(II)

Cytidine

Adenosine

Nitrile insertion

Cytotoxicity

\begin{abstract}
A B S T R A C T
Cytidine (cyt) and adenosine (ado) react with cis- $\left[\mathrm{L}_{2} \mathrm{Pt}(\mu-\mathrm{OH})\right]_{2}\left(\mathrm{NO}_{3}\right)_{2}\left(\mathrm{~L}=\mathrm{PMe}_{3}, \mathrm{PPh}_{3}\right)$ in various solvents to give the nucleoside complexes cis- $\left[\mathrm{L}_{2} \mathrm{Pt}\left\{\operatorname{cyt}(-\mathrm{H}), N^{3} N^{4}\right\}\right]_{3}\left(\mathrm{NO}_{3}\right)_{3}\left(\mathrm{~L}=\mathrm{PMe}_{3}, \mathbf{1}\right)$, cis- $\left[\mathrm{L}_{2} \mathrm{Pt}\left\{\operatorname{cyt}(-\mathrm{H}), N^{4}\right\}\left(\operatorname{cyt}, N^{3}\right)\right]$ $\mathrm{NO}_{3}\left(\mathrm{~L}=\mathrm{PPh}_{3}, 2\right)$, cis- $\left[\mathrm{L}_{2} \mathrm{Pt}\left\{\operatorname{ado}(-\mathrm{H}), N^{1} N^{6}\right\}\right]_{2}\left(\mathrm{NO}_{3}\right)_{2}\left(\mathrm{~L}=\mathrm{PMe}_{3}, 3\right)$ and cis- $\left[\mathrm{L}_{2} \mathrm{Pt}\left\{\operatorname{ado}(-\mathrm{H}), N^{6} N^{7}\right\}\right] \mathrm{NO}_{3}$ $\left(\mathrm{L}=\mathrm{PPh}_{3}, 4\right)$. When the condensation reaction is carried out in solution of nitriles $(\mathrm{RCN}, \mathrm{R}=\mathrm{Me}, \mathrm{Ph})$ the amidine derivatives cis- $\left[\left(\mathrm{PPh}_{3}\right)_{2} \mathrm{PtNH}=\mathrm{C}(\mathrm{R})\{\mathrm{cyt}(-2 \mathrm{H})\}\right] \mathrm{NO}_{3}(\mathrm{R}=\mathrm{Me}, \mathbf{5} \mathbf{a} ; \mathrm{R}=\mathrm{Ph}, \mathbf{5 b})$ and $c i s-\left[\left(\mathrm{PPh}_{3}\right)_{2} \mathrm{PtNH}=\right.$ $\mathrm{C}(\mathrm{R})\{\operatorname{ado}(-2 \mathrm{H})\}] \mathrm{NO}_{3}(\mathrm{R}=\mathrm{Me}, \mathbf{6} \mathbf{a}: \mathrm{R}=\mathrm{Ph}, \mathbf{6} \mathbf{b})$ are quantitatively formed. The coordination mode of these nucleosides, characterized in solution by multinuclear NMR spectroscopy and mass spectrometry, is similar to that previously observed for the nucleobases 1-methylcytosine (1-MeCy) and 9-methyladenine (9-MeAd). The cytotoxic properties of the new complexes, and those of the nucleobase analogs, cis- $\left[\left(\mathrm{PPh}_{3}\right)_{2} \mathrm{PtNH}=\mathrm{C}(\mathrm{R})\right.$ $\{1-\mathrm{MeCy}(-2 \mathrm{H})\}] \mathrm{NO}_{3}(\mathrm{R}=\mathrm{Me}, \mathbf{7 a}: \mathrm{R}=\mathrm{Ph}, \mathbf{7 b})$, cis-[( $\left.\left.\mathrm{PPh}_{3}\right)_{2} \mathrm{PtNH}=\mathrm{C}(\mathrm{R})\{9-\mathrm{MeAd}(-2 \mathrm{H})\}\right] \mathrm{NO}_{3}(\mathrm{R}=\mathrm{Me}, \mathbf{8 a}:$ $\mathrm{R}=\mathrm{Ph}, \mathbf{8 b}$ ) have been investigated in a wide panel of human cancer cells. Interestingly, whereas the $\mathrm{Pt}(\mathrm{II})$ nucleoside complexes (1-4) did not show appreciable cytotoxicity, the corresponding amidine derivatives (7a, $\mathbf{7 b}, \mathbf{8 a}, \mathbf{8 b}, \mathbf{5 b}$, and $\mathbf{6 b}$ ) exhibited a significant in vitro antitumor activity.
\end{abstract}

(c) 2011 Elsevier Inc. All rights reserved.

\section{Introduction}

The coordination chemistry of DNA components to metal centers has been thoroughly characterized [1-3]. In particular, after the discovery of biological activity of cis- $\mathrm{Pt}\left(\mathrm{NH}_{3}\right)_{2} \mathrm{Cl}_{2}$ [4-6], the interactions of platinum (II and IV)[7-10] complexes with model nucleobases, nucleosides and nucleotides, have been studied in great detail [11-17]. In this field we have shown that the neutral ligands in the cisplatin analogs cis-Pt $\left(\mathrm{PR}_{3}\right)_{2} \mathrm{Cl}_{2}\left(\mathrm{PR}_{3}=\right.$ phosphines and diphosphines) play an important role in the nuclearity and reactivity of the platinum-nucleobase adducts. As an example, the reaction of the hydroxo complex cis- $\left[\mathrm{L}_{2} \mathrm{Pt}(\mu-\mathrm{OH})\right]_{2}\left(\mathrm{NO}_{3}\right)_{2}$ with 1-methylcytosine (1-MeCy) causes the deprotonation of the nucleobase leading to cis- $\left[\mathrm{L}_{2} \mathrm{Pt}\left\{\mu-1-\mathrm{MeCy}(-\mathrm{H}), N^{3}, N^{4}\right\}\right]_{3}\left(\mathrm{NO}_{3}\right)_{3}$ when L is $\mathrm{PMe}_{3}[18]$ and to the mononuclear complex cis- $\left[\mathrm{L}_{2} \mathrm{Pt}\left\{1-\mathrm{MeCy}(-\mathrm{H}), N^{4}\right\}\right.$ (1-MeCy, $\left.\left.N^{3}\right)\right] \mathrm{NO}_{3}$ with $\mathrm{L}=\mathrm{PPh}_{3}[19]$. In addition, the trinuclear species is stable in solution of nitriles (MeCN, PhCN), whereas the mononuclear species reacts with the solvent to give the amidine derivatives cis- $\left[\left(\mathrm{PPh}_{3}\right)_{2} \mathrm{PtNH}=\mathrm{C}(\mathrm{R})\{1-\mathrm{MeCy}(-2 \mathrm{H})\}\right] \mathrm{NO}_{3}(\mathrm{R}=\mathrm{Me}, \mathrm{Ph})[20,21]$.

We have now extended these studies on the reactivity of cis- $\left[\mathrm{L}_{2} \mathrm{Pt}\right.$ $(\mu-\mathrm{OH})]_{2}\left(\mathrm{NO}_{3}\right)_{2}\left(\mathrm{~L}=\mathrm{PMe}_{3}, \mathrm{PPh}_{3}\right)$ to the nucleosides cytidine (cyt) and adenosine (ado), shown in Scheme 1.

\footnotetext{
is We would like to dedicate this paper to Dott. Elena Bertacco, a Ph. D. student of our group recently deceased.

* Corresponding author. Tel.: + 39049 8275197; fax: + 390498275161.

E-mail address: bruno.longato@unipd.it (B. Longato).
}

In this paper we report the synthesis and characterization of new nucleoside complexes along with an investigation on their cytotoxic properties against a panel of human cancer cell lines. The high antitumor activity exhibited by the species cis- $\left[\left(\mathrm{PPh}_{3}\right)_{2} \mathrm{PtNH}=\mathrm{C}(\mathrm{Ph})\right.$ $\{\operatorname{cyt}(-2 \mathrm{H})\}] \mathrm{NO}_{3}$ and cis- $\left[\left(\mathrm{PPh}_{3}\right)_{2} \mathrm{PtNH}=\mathrm{C}(\mathrm{Ph})\{\operatorname{ado}(-2 \mathrm{H})\}\right] \mathrm{NO}_{3}$, quantitatively formed when the condensation reaction between the nucleoside and cis- $\left[\left(\mathrm{PPh}_{3}\right)_{2} \mathrm{Pt}(\mu-\mathrm{OH})\right]_{2}\left(\mathrm{NO}_{3}\right)_{2}$ is carried out in benzonitrile, prompted us to include, in this biological investigation, some of the related amidine nucleobase adducts, previously described.

\section{Experimental section}

\subsection{General methods}

Adenosine, cytidine and all the solvents $\left(\mathrm{MeOH}, \mathrm{Et}_{2} \mathrm{O}, \mathrm{PhCN}, \mathrm{CH}_{3} \mathrm{CN}\right.$, DMF (dimethylformamide), $\mathrm{CDCl}_{3}, \mathrm{D}_{2} \mathrm{O}$; DMSO- $d_{6}$, ) are Aldrich products. cis- $\left[\left(\mathrm{PPh}_{3}\right)_{2} \mathrm{Pt}(\mu-\mathrm{OH})\right]_{2}\left(\mathrm{NO}_{3}\right)_{2}[20]$, cis- $\left[\left(\mathrm{PMe}_{3}\right)_{2} \mathrm{Pt}(\mu-\mathrm{OH})\right]_{2}\left(\mathrm{NO}_{3}\right)_{2}[22]$, cis- $\left[\left(\mathrm{PPh}_{3}\right)_{2} \mathrm{PtHN}=\mathrm{C}(\mathrm{Me})\{1-\mathrm{MeCy}(-2 \mathrm{H})\}\right] \mathrm{NO}_{3}$ (7a) [20], cis-[( $\left.\mathrm{PPh}_{3}\right)_{2}$ $\mathrm{PtHN}=\mathrm{C}(\mathrm{Ph})\{1-\mathrm{MeCy}(-2 \mathrm{H})\}] \mathrm{NO}_{3}(\mathbf{7 b})[21]$, cis- $\left[\left(\mathrm{PPh}_{3}\right)_{2} \mathrm{PtHN}=\mathrm{C}(\mathrm{Me})\right.$ $\{9-\mathrm{MeAd}(-2 \mathrm{H})\}] \mathrm{NO}_{3}$ (8a) [20], cis-[( $\left.\mathrm{PPh}_{3}\right)_{2} \mathrm{PtHN}=\mathrm{C}(\mathrm{Me})\{9-\mathrm{MeAd}$ $(-2 \mathrm{H})\}] \mathrm{NO}_{3}(\mathbf{8 b})[21]$ were synthesized as previously reported.

\subsection{NMR and ESI mass spectroscopy}

${ }^{1} \mathrm{H}$ and ${ }^{31} \mathrm{P}$ NMR experiments were recorded on a Bruker AVANCE $300 \mathrm{MHz}$ (operating at 300.13, and $121.49 \mathrm{MHZ}$ respectively) and ${ }^{15} \mathrm{~N}$ 

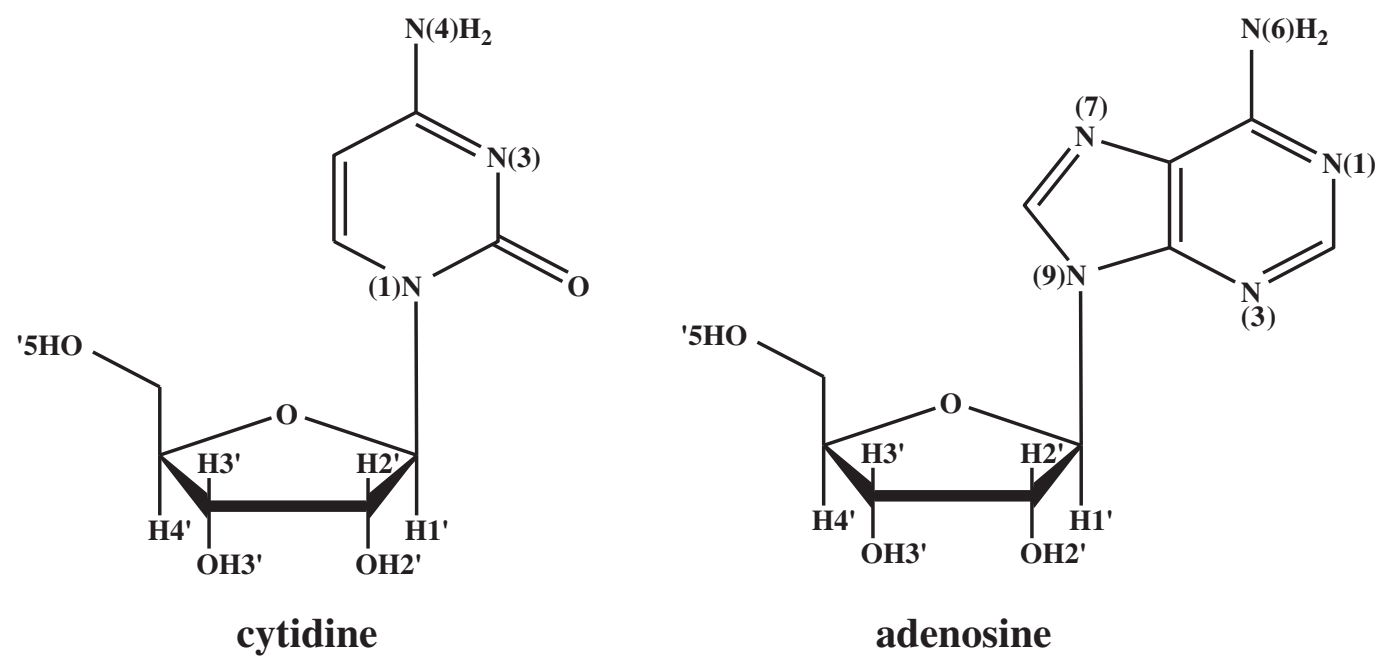

adenosine

Scheme 1. Representation of cytidine (cyt) and adenosine (ado).

NMR with a Bruker 400 AMX-WB spectrometer (operating at $40.6 \mathrm{MHz}$ ). The ${ }^{1} \mathrm{H}$ chemical shifts were referenced to the residual impurity of the solvent and to TMS (tetramethylsilane). The external references were $\mathrm{H}_{3} \mathrm{PO}_{4}\left(85 \% \mathrm{w} / \mathrm{w}\right.$ in $\left.\mathrm{D}_{2} \mathrm{O}\right)$ for ${ }^{31} \mathrm{P}$ and $\mathrm{CH}_{3} \mathrm{NO}_{2}$ (in $\mathrm{CDCl}_{3}$ at $50 \% \mathrm{w} / \mathrm{w}$ ) for ${ }^{15} \mathrm{~N}$. Inverse detected spectra were obtained through heteronuclear multiple bond correlation (HMBC) experiments, using parameters similar to those previously reported [23]. ESI-MS (electrospray ionization mass spectrometry) spectra were performed with a MSD SL trap mass spectrometer (Agilent Technologies, Palo Alto, CA, USA) operating in positive ion mode from $\mathrm{m} / \mathrm{z} 100$ to 2200 . A $5 \times 10^{-6} \mathrm{M}$ solution was directly infused into the ion source at a flow rate of $10 \mu \mathrm{L} \mathrm{min}^{-1}$ by a syringe pump.

\subsection{Synthesis of the complexes}

\subsection{1. $\operatorname{cis}-\left[\left(\mathrm{PMe}_{3}\right)_{2} \mathrm{Pt}\left\{\mathrm{cyd}(-\mathrm{H}), \mathrm{N}^{3} \mathrm{~N}^{4}\right\}\right]_{3}\left(\mathrm{NO}_{3}\right)_{3}$ (1)}

A mixture of cis- $\left[\left(\mathrm{PMe}_{3}\right)_{2} \mathrm{Pt}(\mu-\mathrm{OH})\right]_{2}\left(\mathrm{NO}_{3}\right)_{2}(238 \mathrm{mg}, 0.279 \mathrm{mmol})$ and cytidine (136 mg, $0.56 \mathrm{mmol}$ ) was dissolved in $10 \mathrm{~mL}$ of DMF and the solution was heated at $75{ }^{\circ} \mathrm{C}$ for 10 days. Addition of $\mathrm{Et}_{2} \mathrm{O}$ afforded a yellow oil which, treated several times with $\mathrm{Et}_{2} \mathrm{O}$, became a pale yellow solid. The solid was washed again with $\mathrm{Et}_{2} \mathrm{O}$ and dried under vacuum obtaining $321 \mathrm{mg}$ (yield 88\%). El. An. Calc. per $\mathrm{C}_{15} \mathrm{H}_{30} \mathrm{~N}_{4} \mathrm{O}_{8} \mathrm{P}_{2} \mathrm{Pt}$ - DMF: C: 29.84; H: 5.16; N: 9.66. Found: C: $29.40 ; \mathrm{H}: 4.85 ; \mathrm{N}: 9.42 .{ }^{31} \mathrm{P}\left\{{ }^{1} \mathrm{H}\right\}$ NMR in $\mathrm{D}_{2} \mathrm{O}: \mathrm{AB}$ multiplet at $\delta(\mathrm{ppm})=-28.21\left({ }^{1} J_{\mathrm{PPt}}=3252 \mathrm{~Hz}\right)$ and -30.11 $\left({ }^{1} J_{\mathrm{PPt}}=3117 \mathrm{~Hz}\right)$ with ${ }^{2} J_{\mathrm{PP}}=24.5 \mathrm{~Hz} ; \mathrm{AB}$ multiplet at $\delta(\mathrm{ppm})=$ $-28.25\left({ }^{1} J_{\mathrm{PPt}}=3252 \mathrm{~Hz}\right)$ and $-29.91\left({ }^{1} J_{\mathrm{PPt}}=3117 \mathrm{~Hz}\right)$ with ${ }^{2} J_{\mathrm{PP}}=$ $24.5 \mathrm{~Hz}$. Relative intensities 60/40. ${ }^{1} \mathrm{H}$ NMR in $\mathrm{D}_{2} \mathrm{O}(\delta): 7.56$ and $7.55(\mathrm{~d}$ (doublet), $1 \mathrm{H}, \mathrm{H6},{ }^{3} \mathrm{~J}_{\mathrm{HH}}=7.68 \mathrm{~Hz}$ ); 6.67 and 6.62 (s (singlet), $1 \mathrm{H}, \mathrm{NH}$ ); $6.29\left(\mathrm{~d}, 1 \mathrm{H}, \mathrm{H} 5,{ }^{3} \mathrm{~J}_{\mathrm{HH}}=7.68 \mathrm{~Hz}\right) ; 5.88$ and $5.76\left(\mathrm{~d}, 1 \mathrm{H}, \mathrm{H} 1^{\prime}\right.$, $\left.{ }^{3} J_{\mathrm{HH}}=5.11 \mathrm{~Hz}\right) ; 4.29$ and $4.23\left(1 \mathrm{H}, \mathrm{H}^{\prime}\right) ; 4.11\left(1 \mathrm{H}, \mathrm{H}^{\prime}\right) ; 4.07(1 \mathrm{H}$, $\mathrm{H}^{\prime}$ ); $3.82\left(2 \mathrm{H}, \mathrm{H}^{\prime}\right)$; 1.78 (d, $\left.3 \mathrm{H}, \mathrm{PCH}_{3},{ }^{2} J_{\mathrm{PH}}=11.57 \mathrm{~Hz}\right) ; 1.61(\mathrm{~d}, 3 \mathrm{H}$, $\left.\mathrm{PCH}_{3},{ }^{2} J_{\mathrm{PH}}=10.99 \mathrm{~Hz}\right) .{ }^{31} \mathrm{P}\left\{{ }^{1} \mathrm{H}\right\}$ NMR in DMF ( $\mathrm{D}_{2} \mathrm{O}$ insert $)$ : AB multiplet at $\delta(\mathrm{ppm})=-27.01\left({ }^{1} J_{\mathrm{PPt}}=3126 \mathrm{~Hz}\right)$ and $-28.31\left({ }^{1} J_{\mathrm{PPt}}=3234 \mathrm{~Hz}\right)$ with ${ }^{2} J_{\mathrm{PP}}=24.9 \mathrm{~Hz} ; \mathrm{AB}$ multiplet at $\delta(\mathrm{ppm})=-27.14\left({ }^{1} J_{\mathrm{PPt}}=3126 \mathrm{~Hz}\right)$ and $-28.58\left({ }^{1} J_{\mathrm{PPt}}=3234 \mathrm{~Hz}\right)$ with ${ }^{2} J_{\mathrm{PP}}=24.9 \mathrm{~Hz}$. Relative intensities 65/35. ${ }^{1} \mathrm{H}$ NMR in DMSO- $d_{6}(\delta): 7.49\left(\mathrm{~d}, 1 \mathrm{H}, \mathrm{H} 6,{ }^{3} \mathrm{~J}_{\mathrm{HH}}=8.2 \mathrm{~Hz}\right) ; 7.27(\mathrm{~s}$, $1 \mathrm{H}, \mathrm{NH}) ; 5.97\left(\mathrm{~d}, 1 \mathrm{H}, \mathrm{H} 5,{ }^{3} \mathrm{JH}_{\mathrm{HH}}=8.2 \mathrm{~Hz}\right) ; 5.76\left(\mathrm{~d}, 1 \mathrm{H}, \mathrm{H} 1^{\prime}\right) ; 5.28(\mathrm{~d}, 1 \mathrm{H}$, $\left.\mathrm{OH} 2^{\prime}\right) ; 5.13$ (d, $1 \mathrm{H}, \mathrm{OH}^{\prime}$ ); 5.04 (dd (doublet of doublet), $\left.1 \mathrm{H}, \mathrm{OH} 5^{\prime}\right) ; 3.91$ (d, 1H, H2'); 3.89 (d, 1H, H3); 3.49 (d, 1H, H4' ); 3.52 (d, 2H, H5'); 1.77 (d, $\left.3 \mathrm{H}, \mathrm{PCH}_{3},{ }^{2} J_{\mathrm{PH}}=11.5 \mathrm{~Hz}\right) ; 1.50\left(\mathrm{~d}, 3 \mathrm{H}, \mathrm{PCH}_{3},{ }^{2} J_{\mathrm{PH}}=11.8 \mathrm{~Hz}\right)$. ESI-MS $(\mathrm{m} / \mathrm{z})$ in $\mathrm{MeOH}$, main peak at 915.2 (calc. 914.7) corresponding to the dication cis- $\left[\left(\mathrm{PMe}_{3}\right)_{2} \mathrm{Pt}\{\mathrm{cyd}(-\mathrm{H})\}\right]_{3}\left(\mathrm{NO}_{3}\right)^{2+}$.

In order to analyze the cytotoxic properties of 1 , the compound has been obtained with an analogous procedure in water, heating the sample at $40{ }^{\circ} \mathrm{C}$ for two weeks.

\subsection{2. $\operatorname{cis}-\left[\left(\mathrm{PPh}_{3}\right)_{2} \mathrm{Pt}\left\{\mathrm{cyd}(-\mathrm{H}), \mathrm{N}^{4}\right\}\left(\mathrm{cyd}, \mathrm{N}^{3}\right)\right] \mathrm{NO}_{3}$ (2)}

cis- $\left[\left(\mathrm{PPh}_{3}\right)_{2} \mathrm{Pt}(\mu-\mathrm{OH})\right]_{2}\left(\mathrm{NO}_{3}\right)_{2}(230.9 \mathrm{mg}, 0.145 \mathrm{mmol})$ and cytidine ( $70.5 \mathrm{mg}, 0.26 \mathrm{mmol}$ ) were suspended in $4 \mathrm{~mL}$ of DMF. After $10 \mathrm{~min}$, a pale yellow solution was obtained. After $24 \mathrm{~h}$, addition of $30 \mathrm{~mL}$ of $\mathrm{Et}_{2} \mathrm{O}$ afforded a yellow oil which, following isolation and repeated washes with $\mathrm{Et}_{2} \mathrm{O}$, lead to the formation of a white solid, that was dried under vacuum. The yield of 2 was $314 \mathrm{mg}$ (86\%). El. An. Calc. for $\mathrm{C}_{54} \mathrm{H}_{55} \mathrm{~N}_{7} \mathrm{O}_{13} \mathrm{P}_{2} \mathrm{Pt}$ - DMF: C: $51.08 ; \mathrm{H}: 4.67 ; \mathrm{N}: 8.36$. Found C: $51.92 ; \mathrm{H}: 4.95 ; \mathrm{N}: 8.82$. (Although the analysis value for " $\mathrm{C}$ " is somewhat unsatisfactory, the ${ }^{1} \mathrm{H}$ and ${ }^{31} \mathrm{P}$ NMR data reasonably support the formula). ${ }^{31} \mathrm{P}\left\{{ }^{1} \mathrm{H}\right\}$ NMR in DMF ( $\mathrm{D}_{2} \mathrm{O}$ insert): $\mathrm{AB}$ multiplet at $\delta$ $(\mathrm{ppm})=12.55\left({ }^{1} J_{\mathrm{PPt}}=3194 \mathrm{~Hz}\right)$ and $0.68\left({ }^{1} J_{\mathrm{PPt}}=3586 \mathrm{~Hz}\right)$ with ${ }^{2} J_{\mathrm{PP}}=20.3 \mathrm{~Hz} ; \mathrm{AB}$ multiplet at $\delta(\mathrm{ppm})=12.55\left({ }^{1} J_{\mathrm{PPt}}=3194 \mathrm{~Hz}\right)$ and $1.16\left({ }^{1} J_{\mathrm{PPt}}=3584 \mathrm{~Hz}\right)$ with ${ }^{2} J_{\mathrm{PP}}=20.3$ Relative intensities $75 / 25 \mathrm{~Hz} .{ }^{1} \mathrm{H}$ NMR in DMSO- $d_{6}(\delta)$ : 7.65-7.21 (c.m.(complex multiplet), $31 \mathrm{H}, \mathrm{PPh}_{3}$ and $\mathrm{H} 6$ of $\mathrm{cyd}(-\mathrm{H})$ ); cyd resonances: 10.88 and $10.82(\mathrm{~s}, 1 \mathrm{H}, \mathrm{NH}) ; 8.58$ and $8.55(\mathrm{~s}, 1 \mathrm{H}, \mathrm{NH}) ; 7.22\left(\mathrm{~d}, 1 \mathrm{H}, \mathrm{H} 6,{ }^{3} J_{\mathrm{HH}}=6.78 \mathrm{~Hz}\right) ; 5.30(\mathrm{~d}, 1 \mathrm{H}, \mathrm{H} 5$, $\left.{ }^{3} J_{\mathrm{HH}}=5.67 \mathrm{~Hz}\right) ; \operatorname{cyd}(-\mathrm{H})$ resonances: $7.49\left(\mathrm{~d}, 1 \mathrm{H}, \mathrm{H} 6,{ }^{2} J_{\mathrm{HH}}=7.67 \mathrm{~Hz}\right)$; $5.50(1 \mathrm{H}, \mathrm{NH}) ; 5.09\left(\mathrm{~d}, 1 \mathrm{H}, \mathrm{H} 5,{ }^{3} J_{\mathrm{HH}}=7.67 \mathrm{~Hz}\right)$; ribose resonances: 5.80 $\left(2 \mathrm{H}, \mathrm{OH}^{\prime}\right) ; 5.38\left(2 \mathrm{H}, \mathrm{OH}^{\prime}\right) ; 5.30\left(2 \mathrm{H}, \mathrm{H}^{\prime}\right) ; 5.08\left(2 \mathrm{H}, \mathrm{OH} 4^{\prime}\right) ; 5.00(2 \mathrm{H}$, $\mathrm{OH}^{\prime}$ ); 3.86 (6 H, H2', $\mathrm{H}^{\prime}$ and $\mathrm{H}^{\prime}$ ); 3.58 (4 H, $\mathrm{H}^{\prime}$ ).

\subsection{3. cis- $\left[\left(\mathrm{PMe}_{3}\right)_{2} \mathrm{Pt}\left\{\mathrm{ado}(-\mathrm{H}), \mathrm{N}^{1} \mathrm{~N}^{6}\right\}\right]_{2}\left(\mathrm{NO}_{3}\right)_{2}$ (3)}

cis- $\left[\left(\mathrm{PMe}_{3}\right)_{2} \mathrm{Pt}(\mu-\mathrm{OH})\right]_{2}\left(\mathrm{NO}_{3}\right)_{2}(229.1 \mathrm{mg}, 0.269 \mathrm{mmol})$ and adenosine ( $143.5 \mathrm{mg}, 0.537 \mathrm{mmol}$ ) were dissolved in $10 \mathrm{~mL}$ of $\mathrm{H}_{2} \mathrm{O}$. After 4 days, the solution was dried under vacuum and the solid recrystallized from $\mathrm{MeOH}$ and $\mathrm{Et}_{2} \mathrm{O}$. Obtained $308 \mathrm{mg}$ (yield 85\%). El. An. Calc. for $\mathrm{C}_{16} \mathrm{H}_{30} \mathrm{~N}_{6} \mathrm{O}_{7} \mathrm{P}_{2} \mathrm{Pt} \cdot \mathrm{H}_{2} \mathrm{O}$ : C: $27.71, \mathrm{H}: 4.66, \mathrm{~N}$ : 12.11 . Found: $\mathrm{C}$ : 28.03, $\mathrm{H}: 4.83, \mathrm{~N}: 12.48 .{ }^{31} \mathrm{P}\left\{{ }^{1} \mathrm{H}\right\}$ NMR in $\mathrm{D}_{2} \mathrm{O}: \mathrm{AB}$ multiplet at $\delta$ $(\mathrm{ppm})=-30.78\left({ }^{1} J_{\mathrm{PPt}}=3080 \mathrm{~Hz}\right)$ and $-31.31\left({ }^{1} J_{\mathrm{PPt}}=3238 \mathrm{~Hz}\right)$ with ${ }^{2} J_{\mathrm{PP}}=25.9 \mathrm{~Hz} ;{ }^{1} \mathrm{H}$ NMR in $\mathrm{D}_{2} \mathrm{O}(\delta): 8.16(\mathrm{~s}, 1 \mathrm{H}, \mathrm{H} 8) ; 8.14(\mathrm{~s}, 1 \mathrm{H}, \mathrm{H} 2)$; $6.34(\mathrm{~s}, 1 \mathrm{H}, \mathrm{N} 6 \mathrm{H}) ; 5.77\left(1 \mathrm{H}, \mathrm{H} 1^{\prime}\right) ; 4.24\left(1 \mathrm{H}, \mathrm{H} 2^{\prime}\right) ; 4.10\left(1 \mathrm{H}, \mathrm{H}^{\prime}\right) ; 4.50$ $\left(1 \mathrm{H}, \mathrm{H}^{\prime}\right)$; $3.68\left(2 \mathrm{H}, \mathrm{H} 5^{\prime}\right) ; 1.89\left(\mathrm{~d}, 3 \mathrm{H}, \mathrm{PCH}_{3},{ }^{2} J_{\mathrm{PH}}=10.8 \mathrm{~Hz}\right) ; 1.43(\mathrm{~d}$, $\left.3 \mathrm{H}, \mathrm{PCH}_{3},{ }^{2} J_{\mathrm{PH}}=10.3 \mathrm{~Hz}\right) .{ }^{1} \mathrm{H}$ NMR in DMSO- $d_{6}(\delta): 8.36$ and $8.35(\mathrm{~s}$, $1 \mathrm{H}, \mathrm{H} 8) ; 8.16$ and $8.14(\mathrm{~s}, 1 \mathrm{H}, \mathrm{H} 2) ; 6.81$ and $6.78(\mathrm{~s}, 1 \mathrm{H}, \mathrm{N} 6 \mathrm{H}) ; 5.71(1 \mathrm{H}$, $\left.\mathrm{OH} 2^{\prime}\right) ; 5.41$ e $5.38\left(1 \mathrm{H}, \mathrm{H}^{\prime}\right) ; 5.19\left(1 \mathrm{H}, \mathrm{OH}^{\prime}\right) ; 5.03\left(1 \mathrm{H}, \mathrm{OH}^{\prime}\right) ; 4.37$ (1H, H2'); 4.06 (1H, H3'); $3.86\left(1 \mathrm{H}, \mathrm{H}^{\prime}\right)$; $3.54\left(2 \mathrm{H}, \mathrm{H} 5^{\prime}\right) ; 1.87$ (d, $3 \mathrm{H}$, $\left.\mathrm{PCH}_{3},{ }^{2} J_{\mathrm{PH}}=11.1 \mathrm{~Hz}\right) ; 1.44\left(\mathrm{~d}, 3 \mathrm{H}, \mathrm{PCH}_{3},{ }^{2} J_{\mathrm{PH}}=10.4 \mathrm{~Hz}\right)$.

\subsection{4. $\operatorname{cis}-\left[\left(\mathrm{PPh}_{3}\right)_{2} \mathrm{Pt}\left\{\mathrm{ado}(-\mathrm{H}), \mathrm{N}^{6} \mathrm{~N}^{7}\right\}\right] \mathrm{NO}_{3}$ (4)}

cis- $\left[\left(\mathrm{PPh}_{3}\right)_{2} \mathrm{Pt}(\mu-\mathrm{OH})\right]_{2}\left(\mathrm{NO}_{3}\right)_{2}(230.5 \mathrm{mg}, 0.144 \mathrm{mmol})$ and adenosine (77.1 mg, $0.286 \mathrm{mmol}$ ) were suspended in a mixture of $\mathrm{CH}_{2} \mathrm{Cl}_{2}$ and $\mathrm{MeOH}(3+3 \mathrm{~mL})$. After $30 \mathrm{~min}$ of stirring, a pale yellow solution was obtained. After $24 \mathrm{~h}$ the addition of $30 \mathrm{~mL}$ of $\mathrm{Et}_{2} \mathrm{O}$ afforded a yellow oil which, after being isolated and washed several times with 
$\mathrm{Et}_{2} \mathrm{O}$, led to the formation of a white solid which has been dried under vacuum. Obtained $252 \mathrm{mg}$ (yield 83\%). El. An. Calc. for $\mathrm{C}_{46} \mathrm{H}_{42} \mathrm{~N}_{6} \mathrm{O}_{7} \mathrm{P}_{2} \mathrm{Pt} \cdot-$ $\mathrm{H}_{2} \mathrm{O}: \mathrm{C}: 51.83 ; \mathrm{H}: 4.17 ; \mathrm{N}: 7.88$. Found C: $51.47 ; \mathrm{H}: 4.42 ; \mathrm{N}: 7.98 .{ }^{1} \mathrm{H}$ NMR in DMSO-d D $_{6}(\delta): 8.05$ (s, 1H, H2); 7.74-7.10 (c.m. 30 H, PPh $) ; 6.76$ (s, $1 \mathrm{H}, \mathrm{H} 8) ; 5.87\left(\mathrm{~d}, 1 \mathrm{H}, \mathrm{OH} 2^{\prime}, 3_{\mathrm{HH}}=6.1 \mathrm{~Hz}\right) ; 5.38\left(\mathrm{~d}, 1 \mathrm{H}, \mathrm{OH} 3^{\prime}, 3_{\mathrm{HH}}=\right.$ $5.9 \mathrm{~Hz}) ; 5.20\left(2 \mathrm{H}, \mathrm{H}^{\prime}{ }^{\prime}\right.$ e $\left.\mathrm{NH}\right) ; 5.04\left(1 \mathrm{H}, \mathrm{OH} 5^{\prime}\right) ; 4.42\left(1 \mathrm{H}, \mathrm{H} 2^{\prime}\right) ; 4.30(1 \mathrm{H}$, $\left.\mathrm{H}^{\prime}\right)$; $4.14\left(1 \mathrm{H}, \mathrm{H} 4^{\prime}\right) ; 3.95\left(1 \mathrm{H}, \mathrm{H} 5^{\prime}\right) ; 3.88\left(1 \mathrm{H}, \mathrm{H} 5^{\prime \prime}\right) .{ }^{31} \mathrm{P}\left\{{ }^{1} \mathrm{H}\right\} \mathrm{NMR}$ in $\mathrm{CDCl}_{3}$ : $\mathrm{AB}$ multiplet at $\delta(\mathrm{ppm})=8.29\left({ }^{1} \mathrm{JPPt}_{\mathrm{Pt}}=3844 \mathrm{~Hz}\right)$ and 6.58 $\left({ }^{1} J_{\mathrm{PPt}}=3124 \mathrm{~Hz}\right)$ with ${ }^{2} J_{\mathrm{PP}}=20.2 \mathrm{~Hz} ;{ }^{1} \mathrm{H} \mathrm{NMR}$ in $\mathrm{CDCl}_{3}(\delta): 8.12(\mathrm{~s}, 1 \mathrm{H}$, H2); 7.55-7.27 (c.m. $30 \mathrm{H}, \mathrm{PPh}_{3}$ ); 6.39 (d, $1 \mathrm{H}, \mathrm{OH}^{\prime},{ }^{3} J_{\mathrm{HH}}=9.88 \mathrm{~Hz}$ ); $6.28\left(\mathrm{~d}, 1 \mathrm{H}, \mathrm{OH} 2^{\prime},{ }^{3} \mathrm{H}_{\mathrm{HH}}=6.58 \mathrm{~Hz}\right) ; 5.83(\mathrm{~s}, 1 \mathrm{H}, \mathrm{H} 8) ; 5.43\left(\mathrm{~d}, 1 \mathrm{H}, \mathrm{H} 1^{\prime}\right.$, $\left.{ }^{3} \mathrm{~J}_{\mathrm{HH}}=6.97 \mathrm{~Hz}\right) ; 4.66\left(2 \mathrm{H}, \mathrm{H}^{\prime}{ }^{\prime}\right.$ e NH$) ; 4.36\left(2 \mathrm{H}, \mathrm{H}^{\prime}\right.$ and $\left.\mathrm{OH}^{\prime}\right) ; 4.26(1 \mathrm{H}$, $\mathrm{H} 4^{\prime}$ ); $3.89 \div 3.66$ (c.m. $2 \mathrm{H}, \mathrm{H} 5^{\prime}$ ). ${ }^{15} \mathrm{~N}$ NMR (inverse detected) in $\mathrm{CDCl}_{3}$

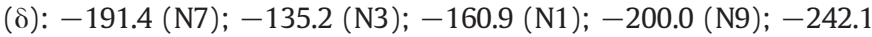
(N6). ESI-MS $(\mathrm{m} / \mathrm{z})$ in $\mathrm{MeOH}$, main peak at 985.4 (calc. 985.2) corresponding to the monocation cis- $\left[\left(\mathrm{PPh}_{3}\right)_{2} \mathrm{Pt}\{\operatorname{ado}(-\mathrm{H})\}\right]^{+}$.

\subsection{5. $\operatorname{cis}-\left[\left(\mathrm{PPh}_{3}\right)_{2} \mathrm{PtHN}=\mathrm{C}(\mathrm{Me})\{\mathrm{cyt}(-2 \mathrm{H})\}\right] \mathrm{NO}_{3}(5 \mathrm{a})$}

cis- $\left[\left(\mathrm{PPh}_{3}\right)_{2} \mathrm{Pt}(\mu-\mathrm{OH})\right]_{2}\left(\mathrm{NO}_{3}\right)_{2},(45 \mathrm{mg}, 0.028 \mathrm{mmol})$ and cytidine (14 mg, $0.057 \mathrm{mmol}$ ) were suspended in $5 \mathrm{~mL}$ of $\mathrm{CH}_{3} \mathrm{CN}$. After stirring at r.t. for $24 \mathrm{~h}$, some traces of solid were removed by filtration. Addition of $\mathrm{Et}_{2} \mathrm{O}$ to the resulting pale yellow solution, afforded a pale yellow solid which was recovered by filtration, washed with $\mathrm{Et}_{2} \mathrm{O}$ and dried under vacuum. The amount of $\mathbf{5 a}$ obtained was $46 \mathrm{mg}$ (yield 76\%). El. An. Calc. for $\mathrm{C}_{47} \mathrm{H}_{45} \mathrm{~N}_{5} \mathrm{O}_{8} \mathrm{P}_{2} \mathrm{Pt}$ : C: $53.01 ; \mathrm{H}$ : 4.27; N: 6.57. Found: C: 52.75; $\mathrm{H}: 4.18$; N: $6.40 .{ }^{31} \mathrm{P}\left\{{ }^{1} \mathrm{H}\right\} \mathrm{NMR}$ in $\mathrm{CH}_{3} \mathrm{CN}\left(\mathrm{D}_{2} \mathrm{O}\right.$ insert): $\mathrm{AB}$ multiplet at $\delta(\mathrm{ppm})=9.11\left({ }^{1} J_{\mathrm{PPt}}=\right.$ $3481 \mathrm{~Hz})$ and $8.71\left({ }^{1} J_{\mathrm{PPt}}=3465 \mathrm{~Hz}\right)$ with ${ }^{2} J_{\mathrm{PP}}=21.1 \mathrm{~Hz} .{ }^{1} \mathrm{H}$ NMR in $\mathrm{CDCl}_{3}(\delta, \mathrm{ppm}): 7.95\left(\mathrm{~d}, 1 \mathrm{H}, \mathrm{H} 6,{ }^{3} J_{\mathrm{HH}}=7.45 \mathrm{~Hz}\right) ; 7.65-7.14$ (c.m. $\left.30 \mathrm{H}, \mathrm{PPh}_{3}\right) ; 6.00\left(\mathrm{~d}, 1 \mathrm{H}, \mathrm{H} 5,{ }^{3} \mathrm{JHH}_{\mathrm{HH}}=7.45 \mathrm{~Hz}\right) ; 5.50(\mathrm{br} \mathrm{dd}, 1 \mathrm{H}, \mathrm{NH})$; $5.40\left(1 \mathrm{H}, \mathrm{H}^{\prime}\right)$; $4.82\left(\mathrm{~s}, 1 \mathrm{H}, \mathrm{OH} 2^{\prime}\right) ; 4.20\left(1 \mathrm{H}, \mathrm{H} 2^{\prime}\right) ; 4.13\left(1 \mathrm{H}, \mathrm{H}^{\prime}\right)$; $3.93\left(1 \mathrm{H}, \mathrm{OH}^{\prime}\right)$; $3.87\left(2 \mathrm{H}, \mathrm{CH}^{\prime}\right)$; $3.81\left(1 \mathrm{H}, \mathrm{OH}^{\prime}\right)$; $3.73\left(1 \mathrm{H}, \mathrm{H} 4^{\prime}\right)$.

\subsection{6. $\operatorname{cis}-\left[\left(\mathrm{PPh}_{3}\right)_{2} \mathrm{PtHN}=\mathrm{C}(\mathrm{Ph})\{\mathrm{Cyt}(-2 \mathrm{H})\}\right] \mathrm{NO}_{3}(5 \mathrm{~b})$}

cis- $\left[\left(\mathrm{PPh}_{3}\right)_{2} \mathrm{Pt}(\mu-\mathrm{OH})\right]_{2}\left(\mathrm{NO}_{3}\right)_{2},(30.9 \mathrm{mg}, 0.0193 \mathrm{mmol})$ and cytidine ( $9.8 \mathrm{mg}, 0.0387 \mathrm{mmol}$ ) were suspended in $5 \mathrm{~mL}$ of PhCN and heated at $50{ }^{\circ} \mathrm{C}$ for $1 / 2 \mathrm{~h}$. After stirring at r.t. for $24 \mathrm{~h}$, some traces of solid were removed by filtration. Addition of $\mathrm{Et}_{2} \mathrm{O}$ to the resulting yellow solution, afforded a yellow solid which was recovered by filtration, washed with $\mathrm{Et}_{2} \mathrm{O}$ and dried under vacuum. $25 \mathrm{mg}$ of compound $\mathbf{5 b}$ were obtained (yield 57\%). El. An. Calc. for $\mathrm{C}_{52} \mathrm{H}_{47} \mathrm{~N}_{5} \mathrm{O}_{8} \mathrm{P}_{2} \mathrm{Pt}$ : C: 55.42; $\mathrm{H}: 4.21$; N: 6.21 . Found: C: 55.82; $\mathrm{H}: 4.44 ; \mathrm{N}: 6.45 .{ }^{31} \mathrm{P}\left\{{ }^{1} \mathrm{H}\right\}$ NMR in PhCN ( $\mathrm{D}_{2} \mathrm{O}$ insert): $\mathrm{AB}$ multiplet at $\delta(\mathrm{ppm})=7.90\left({ }^{1} J_{\mathrm{PPt}}=3436 \mathrm{~Hz}\right)$ and $7.65\left({ }^{1} J_{\mathrm{PPt}}=3436 \mathrm{~Hz}\right)$ with $\left.{ }^{2} J_{\mathrm{PP}}=25.1 \mathrm{~Hz}\right),{ }^{1} \mathrm{H}$ NMR in $\mathrm{CDCl}_{3}(\delta, \mathrm{ppm}): 7.98\left(\mathrm{~d}, 1 \mathrm{H}, \mathrm{H} 6,{ }^{3} J_{\mathrm{HH}}=\right.$ $7.20 \mathrm{~Hz}$ ); 7.68-7.07 (c.m. $\left.30 \mathrm{H}, \mathrm{PPh}_{3}\right) ; 6.24$ (d, $1 \mathrm{H}, \mathrm{H} 5,{ }^{3} J_{\mathrm{HH}}=7.20 \mathrm{~Hz}$ ); 6.00 (br dd (broad doublet of doublet), $\left.1 \mathrm{H}, \mathrm{NH},{ }^{3} \mathrm{~J}_{\mathrm{HP}}=5.3 \mathrm{~Hz}\right) ; 5.40(1 \mathrm{H}$, $\left.\mathrm{H}^{\prime}\right)$; 4.87 (s, 1H, OH2'); 4.30 (1H, H2'); $4.06\left(1 \mathrm{H}, \mathrm{H}^{\prime}\right)$; 3.93 (3 H, H5' and $\left.\mathrm{OH}^{\prime}\right) ; 3.77\left(1 \mathrm{H}, \mathrm{H}^{\prime}\right) ; 3.67\left(\mathrm{~s}, 1 \mathrm{H}, \mathrm{OH}^{\prime}\right)$.

\subsection{7. cis- $\left[\left(\mathrm{PPh}_{3}\right)_{2} \mathrm{PtHN}=\mathrm{C}(\mathrm{Me})\{\mathrm{Ado}(-2 \mathrm{H})\}\right] \mathrm{NO}_{3}(6 \mathrm{a})$}

This complex has been synthesized in the same way of 5a starting from cis- $\left[\left(\mathrm{PPh}_{3}\right)_{2} \mathrm{Pt}(\mu-\mathrm{OH})\right]_{2}\left(\mathrm{NO}_{3}\right)_{2},(50.4 \mathrm{mg}, 0.032 \mathrm{mmol})$ and adenosine ( $16 \mathrm{mg}, 0.06 \mathrm{mmol}$ ). The reaction mixture was stirred for 5 days at r.t., obtaining $48 \mathrm{mg}$ (yield $73 \%$ ) of product.

El. An. Calc. for $\mathrm{C}_{48} \mathrm{H}_{45} \mathrm{~N}_{7} \mathrm{O}_{7} \mathrm{P}_{2} \mathrm{Pt}: \mathrm{C}: 52.94 ; \mathrm{H}: 4.17 ; \mathrm{N}: 9.00$. Found: C: $52.62 ; \mathrm{H}: 4.28 ; \mathrm{N}: 8.85 .{ }^{31} \mathrm{P}\left\{{ }^{1} \mathrm{H}\right\} \mathrm{NMR}$ and $\mathrm{CH}_{3} \mathrm{CN}\left(\mathrm{D}_{2} \mathrm{O}\right.$ insert): $\mathrm{AB}$ multiplet at $\delta(\mathrm{ppm})=12.11\left({ }^{1} \mathrm{PPt}_{\mathrm{P}}=3254 \mathrm{~Hz}\right)$ and $10.46\left({ }^{1} \mathrm{JPt}_{\mathrm{PPt}}=\right.$ $3419 \mathrm{~Hz})$ with ${ }^{2} J_{\mathrm{PP}}=24.9 \mathrm{~Hz}$.

${ }^{1} \mathrm{H}$ NMR in $\mathrm{CDCl}_{3}(\delta, \mathrm{ppm}): 8.02(\mathrm{~s}, 1 \mathrm{H}, \mathrm{H} 2) ; 7.63-7.20($ c.m. $31 \mathrm{H}$, $\mathrm{PPh}_{3}$ and $\left.\mathrm{H} 8\right) ; 6.35$ (br s, $\left.1 \mathrm{H}, \mathrm{NH}\right) ; 5.72$ (br dd, $\left.1 \mathrm{H}, \mathrm{H} 1^{\prime}\right) 5.68$ (br s, $1 \mathrm{H}$, $\left.\mathrm{H}^{\prime}\right)$; $4.95\left(1 \mathrm{H}, \mathrm{OH}^{\prime}\right)$; 4.25 ( $3 \mathrm{H}, \mathrm{H}^{\prime}{ }^{\prime}$; $\mathrm{H}^{\prime}$ and $\left.\mathrm{OH}^{\prime}\right)$; $4.16\left(1 \mathrm{H}, \mathrm{OH}^{\prime}\right)$; $3.66\left(2 \mathrm{H}, \mathrm{H} 5^{\prime}\right)$.

\subsection{8. $\operatorname{cis}-\left[\left(\mathrm{PPh}_{3}\right)_{2} \mathrm{PtHN}=\mathrm{C}(\mathrm{Ph})\{\mathrm{Ado}(-2 \mathrm{H})\}\right] \mathrm{NO}_{3}(6 \mathrm{~b})$}

This complex has been synthesized in the same way of $\mathbf{6 a}$ starting from cis- $\left[\left(\mathrm{PPh}_{3}\right)_{2} \mathrm{Pt}(\mu-\mathrm{OH})\right]_{2}\left(\mathrm{NO}_{3}\right)_{2},(32.8 \mathrm{mg}, 0.02 \mathrm{mmol})$ and aden- osine (11 mg, $0.04 \mathrm{mmol}$ ). $29 \mathrm{mg}$ of compound $\mathbf{6 b}$ were obtained (yield 61\%). El. An. Calc. for $\mathrm{C}_{53} \mathrm{H}_{47} \mathrm{~N}_{7} \mathrm{O}_{7} \mathrm{P}_{2} \mathrm{Pt}$ : C: 55.30; $\mathrm{H}: 4.12 ; \mathrm{N}$ : 8.51. Found: C: 55.70 ; $\mathrm{H}: 4.32$; $: 8.75 .{ }^{31} \mathrm{P}\left\{{ }^{1} \mathrm{H}\right\}$ NMR in $\mathrm{PhCN}\left(\mathrm{D}_{2} \mathrm{O}\right.$ insert $)$ : $\mathrm{AB}$ multiplet at $\delta(\mathrm{ppm})=11.00\left({ }^{1} \mathrm{JPt}_{\mathrm{PPt}}=3281 \mathrm{~Hz}\right)$ and 9.35 $\left({ }^{1} J_{\mathrm{PPt}}=3393 \mathrm{~Hz}\right)$ with ${ }^{2} J_{\mathrm{PP}}=24.6 \mathrm{~Hz}^{1} \mathrm{H} \mathrm{NMR}$ in $\mathrm{CDCl}_{3}(\delta, \mathrm{ppm}): 8.06$ (s, $1 \mathrm{H}, \mathrm{H} 2$ ); 7.65-7.14(c.m. $31 \mathrm{H}, \mathrm{PPh}_{3}$ and $\mathrm{H}(8)$ ); 6.24 (br s, $\left.1 \mathrm{H}, \mathrm{NH}\right)$; 5.73 (br dd 2H, $\mathrm{H}^{\prime}$ and $\mathrm{H}^{\prime}$ '); 4.99 (1 $\left.\mathrm{H}, \mathrm{OH} 2^{\prime}\right) ; 4.38$ (3 H, $\mathrm{H}^{\prime}$; $\mathrm{H}^{\prime}{ }^{\prime}$ and $\left.\mathrm{OH}^{\prime}\right)$ ); 4.18 (1H, $\left.\mathrm{OH}^{\prime}\right)$; 3.65 (2H, H5').

\subsection{Experiments with human cell lines}

$\mathrm{Pt}$ (II) nucleosides (1-4) as well as the corresponding Pt(II) amidine nucleoside (5b, 6b) and nucleobase (7a, 7b, 8a, and $\mathbf{8 b}$ ) derivatives were dissolved in DMSO just before the experiment and a calculated amount of drug solution was added to the growth medium. The final solvent concentration was $0.5 \%$, which had no discernible effect on cell killing. Cisplatin was dissolved in purified water just before the experiment. MTT (3-(4,5-dimethylthiazol-2-yl)-2,5-diphenyltetrazolium bromide) and cisplatin were obtained from Sigma Chemical Co, St.Louis, USA.

\subsubsection{Cell cultures}

Human breast (MCF-7) carcinoma cell line along with melanoma (A375) cell line were obtained by American Type Culture Collection (ATCC, Rockville, MD). 2008 and its cisplatin resistant variant, C13*, are human ovarian cancer cell lines, and they were kindly provided by Prof. G. Marverti (Dept. of Biomedical Science of Modena University, Italy). A431 and A431/Pt are sensitive and resistant human cervical carcinoma cells, respectively; kindly provided by Prof. F. Zunino (Division of Experimental Oncology B, Istituto Nazionale dei Tumori, Milan, Italy). LoVo human colon-carcinoma cell line and its derivative multidrugresistant sub-line (LoVo MDR) were kindly provided by Prof. F. Majone (Dept. of Biology of Padova University, Italy). Cell lines were maintained in the logarithmic phase at $37^{\circ} \mathrm{C}$ in a $5 \%$ carbon dioxide atmosphere using the following culture media containing $10 \%$ fetal calf serum (Euroclone, Milan, Italy), antibiotics (50 units $\cdot \mathrm{mL}^{-1}$ penicillin and $50 \mu \mathrm{g} \cdot \mathrm{mL}^{-1}$ streptomycin) and $2 \mathrm{mM}$ L-glutamine: i) RPMI-1640 medium (Euroclone) for MCF-7, 2008, C13* cells; ii) F-12 HAM'S (Sigma Chemical Co) for A431, A431/Pt cells LoVo and LoVo MDR (LoVo MDR culture medium also contained $0.1 \mu \mathrm{g} \cdot \mathrm{mL}^{-1}$ doxorubicin); iii) d-MEM “Dulbecco's modified eagle's medium” (Euroclone) for A375 cells.

\subsubsection{Cytotoxicity assays}

MTT test. The growth inhibitory effect towards tumor cell lines was evaluated by means of MTT (tetrazolium salt reduction) assay $[24,25]$. Briefly, $3-8 \cdot 10^{3}$ cells/well, dependent upon the growth characteristics of the cell line, were seeded in 96-well microplates in growth medium $(100 \mu \mathrm{L})$ and then incubated at $37{ }^{\circ} \mathrm{C}$ in a $5 \%$ carbon dioxide atmosphere. After $24 \mathrm{~h}$, the medium was removed and replaced with a fresh one containing the compound to be studied at the appropriate concentration. Triplicate cultures were established for each treatment. After $72 \mathrm{~h}$, each well was treated with $10 \mu \mathrm{L}$ of a $5 \mathrm{mg} \cdot \mathrm{mL}^{-1}$ MTT saline solution, and following $5 \mathrm{~h}$ of incubation, $100 \mu \mathrm{L}$ of an SDS solution in $\mathrm{HCl} 0.01 \mathrm{M}$ was added. After overnight incubation, the inhibition of cell growth induced by the tested complexes was detected by measuring the absorbance of each well at $570 \mathrm{~nm}$ using a Bio-Rad 680 microplate reader. Mean absorbance for each drug dose was expressed as a percentage of the control untreated well absorbance and plotted vs. drug concentration. $\mathrm{IC}_{50}$ values represent the drug concentrations that reduced the mean absorbance at $570 \mathrm{~nm}$ to $50 \%$ of those in the untreated control wells. 


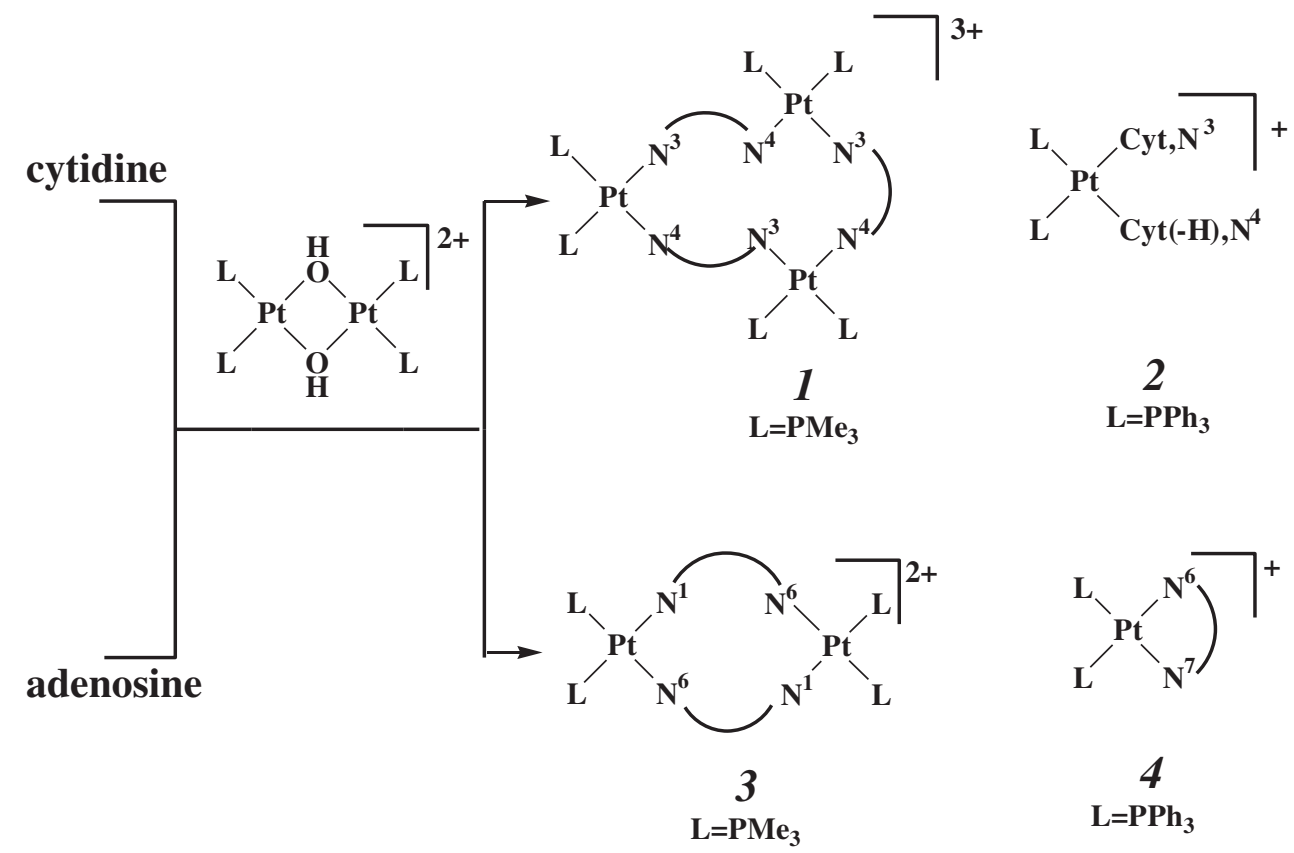

Scheme 2. Pathway reaction for the nucleosides Pt(II) complexes 1-4.

\section{Results and discussion}

\subsection{Syntheses of the nucleoside complexes}

As previously shown for the model nucleobase 1-MeCy [18], cytidine reacts with the dinuclear hydroxo complex cis-[( $\left.\mathrm{PMe}_{3}\right)_{2} \mathrm{Pt}$ $(\mu-\mathrm{OH})]_{2}\left(\mathrm{NO}_{3}\right)_{2}$, to give the trinuclear species cis-[( $\left.\mathrm{PMe}_{3}\right)_{2} \mathrm{Pt}\{\mu$-cyt $\left.\left.(-\mathrm{H}), N^{3} N^{4}\right\}\right]_{3}\left(\mathrm{NO}_{3}\right)_{3}, \mathbf{1}$, in which the $\mathrm{N}(4)$-deprotonated nucleoside binds two metal centers through the N3,N4 atoms (Scheme 2).

The condensation reaction, carried out in DMF solution was monitored by ${ }^{31} \mathrm{P}$ NMR spectroscopy showing that, at room temperature, a complex mixture of products is formed. At $70{ }^{\circ} \mathrm{C}$, in a few days, it converts quantitatively into the trinuclear species 1 characterized by two $A B$ multiplets, having relative intensities of $2: 1$, at $\delta-27.01\left({ }^{1} J_{\mathrm{PPt}}=\right.$ $3126 \mathrm{~Hz}), 28.31(3234 \mathrm{~Hz})$ at $\delta-27.14\left({ }^{1} J_{\mathrm{PPt}}=3126 \mathrm{~Hz}\right), 28.58$ $\left(3234 \mathrm{~Hz}\right.$, with $\left.{ }^{2} J_{\mathrm{PP}}=24.8 \mathrm{~Hz}\right) \mathrm{ppm}$, respectively. The ${ }^{31} \mathrm{P}$ NMR parameters of the isolated complex, in DMSO- $d_{6}$, collected in Table 1 , are very similar to those of the nucleobase analogous, structurally characterized [18]. The presence of two sets of signals for the nucleoside is in line with the existence of two conformers resulting in the relative orientation, syn and anti, of the ribose groups with respect to the pyrimidinic ring.
The nature of the phosphine ligands plays an important role on the nuclearity of the nucleoside adducts. In fact, reaction of cytidine with cis- $\left[\left(\mathrm{PPh}_{3}\right)_{2} \mathrm{Pt}(\mu-\mathrm{OH})\right]_{2}\left(\mathrm{NO}_{3}\right)_{2}$ gives only the mononuclear bis-adduct cis- $\left[\left(\mathrm{PPh}_{3}\right)_{2} \mathrm{Pt}\left\{\mathrm{cyt}(-\mathrm{H}), N^{4}\right\}\left(\mathrm{cyt}, N^{3}\right)\right] \mathrm{NO}_{3}, 2$, containing two molecules of nucleoside, one neutral N3-coordinated, and one N4-deprotonated, coordinated at the same metal center (Scheme 2).

Similarly, adenosine reacts with cis- $\left[\left(\mathrm{PPh}_{3}\right)_{2} \mathrm{Pt}(\mu-\mathrm{OH})\right]_{2}\left(\mathrm{NO}_{3}\right)_{2}$ giving the mononuclear species cis- $\left[\left(\mathrm{PPh}_{3}\right)_{2} \mathrm{Pt}\left\{\operatorname{ado}(-\mathrm{H}), N^{6} N^{7}\right\}\right] \mathrm{NO}_{3}$, 4, in which the $\mathrm{N}(6)$-deprotonated nucleoside binds the metal center through the N6,N7 atoms (Scheme 2). On the contrary, cis-[( $\left.\mathrm{PMe}_{3}\right)_{2} \mathrm{Pt}$ $(\mu-\mathrm{OH})]_{2}\left(\mathrm{NO}_{3}\right)_{2}$, forms the cyclic dinuclear species cis-[(PMe $)_{2} \mathrm{Pt}\{\mu-$ $\left.\left.\operatorname{ado}(-\mathrm{H}), N^{1} N^{6}\right\}\right]_{2}\left(\mathrm{NO}_{3}\right)_{2}, 3$, in which the adenosinate ions act as bridging ligands, binding two metal centers through the N1 and N6 atoms.

The reaction of the hydroxo complex with the bulkier $\mathrm{PPh}_{3}$ ligands, was carried out in DMF or $\mathrm{CH}_{2} \mathrm{Cl}_{2} / \mathrm{MeOH}$ solution and monitored by ${ }^{31} \mathrm{P}$ NMR spectroscopy. In both cases, complex $\mathbf{4}$ was formed in high yield $(>80 \%)$. The ${ }^{1} \mathrm{H}$ and ${ }^{31} \mathrm{P}$ analysis of the isolated solid indicates the formation of a single species whose proton resonances were attributed analyzing the COSY $\left({ }^{1} \mathrm{H}-{ }^{1} \mathrm{H}\right.$ COrrelation NMR SpectroscopY) spectrum (reported in Fig. S1 of the Supplementary Material)

Table 1

${ }^{31} \mathrm{P}$ and selected ${ }^{1} \mathrm{H}$ NMR data in DMSO- $d_{6}$ for the complexes 1-4 and the analogous complexes with the corresponding nucleobases. $\delta$ in ppm and $J$ in $\mathrm{Hz}$.

\begin{tabular}{|c|c|c|c|c|c|c|}
\hline Compound & $\mathrm{P}_{\mathrm{A}}\left({ }^{1} J_{\mathrm{PPt}}\right)$ & $\mathrm{P}_{\mathrm{B}}\left({ }^{1} J_{\mathrm{PPt}}\right)$ & ${ }^{2} J_{\mathrm{PP}}$ & $\mathrm{H} 2 / \mathrm{H} 5$ & $\mathrm{H} 8 / \mathrm{H} 6$ & NH6/NH4 \\
\hline cis- $\left[\left(\mathrm{PMe}_{3}\right)_{2} \mathrm{Pt}\left\{\operatorname{cyd}(-\mathrm{H}), N^{3} N^{4}\right\}\right]_{3}\left(\mathrm{NO}_{3}\right)_{3} \mathbf{1}$ & $\begin{array}{l}-27.06(3266) \\
-27.26(3266)\end{array}$ & $\begin{array}{l}-28.59(3097) \\
-28.33(3097)\end{array}$ & $\begin{array}{l}20.4 \\
20.6\end{array}$ & 5.97 & 7.49 & 7.27 \\
\hline $\begin{array}{l}\text { cis- }\left[\left(\mathrm{PMe}_{3}\right)_{2} \mathrm{Pt}\left\{1-\mathrm{MeCy}(-\mathrm{H}), N^{3} N^{4}\right\}\right]_{3}\left(\mathrm{NO}_{3}\right)_{3}[18] \\
\operatorname{cis}-\left[\left(\mathrm{PPh}_{3}\right)_{2} \mathrm{Pt}\left\{\operatorname{cyd}(-\mathrm{H}), N^{4}\right\}\left(\mathrm{cyd}, N^{3}\right)\right] \mathrm{NO}_{3} 2\end{array}$ & $\begin{array}{r}-27.77(3221) \\
12.14(3190) \\
12.11(3190)\end{array}$ & $\begin{array}{r}-29.14(3135) \\
0.36(3615) \\
0.41(3615)\end{array}$ & $\begin{array}{l}24.4 \\
20.4 \\
20.6\end{array}$ & $\begin{array}{l}6.05 \\
5.30 \\
5.09\end{array}$ & $\begin{array}{l}7.44 \\
7.22 \\
7.49\end{array}$ & $\begin{array}{l}6.46 \\
8.58 \\
8.55 \\
5.50\end{array}$ \\
\hline cis- $\left[\left(\mathrm{PPh}_{3}\right)_{2} \mathrm{Pt}\left\{1-\mathrm{MeCy}(-\mathrm{H}), N^{4}\right\}\left(1-\mathrm{MeCy}, N^{3}\right)\right] \mathrm{NO}_{3}[19]$ & $12.34(3241)$ & $0.21(3452)$ & 20.0 & $\begin{array}{l}5.25 \\
4.98\end{array}$ & 6.66 & $\begin{array}{r}10.63 \\
8.34 \\
5.07\end{array}$ \\
\hline $\operatorname{cis}-\left[\left(\mathrm{PMe}_{3}\right)_{2} \mathrm{Pt}\left\{\operatorname{ado}(-\mathrm{H}), N^{1} N^{6}\right\}\right]_{2}\left(\mathrm{NO}_{3}\right)_{2} 3$ & $\begin{array}{l}-29.81(3025) \\
-29.83(3025)\end{array}$ & $\begin{array}{l}-30.48(3233) \\
-38.38(3233)\end{array}$ & $\begin{array}{l}26.4 \\
26.6\end{array}$ & $\begin{array}{l}8.36 \\
8.35\end{array}$ & $\begin{array}{l}8.16 \\
8.14\end{array}$ & $\begin{array}{l}6.81 \\
6.78\end{array}$ \\
\hline $\begin{array}{l}\operatorname{cis}-\left[\left(\mathrm{PMe}_{3}\right)_{2} \mathrm{Pt}\left\{9-\mathrm{MeAd}(-\mathrm{H}), N^{1} N^{6}\right\}\right]_{2}\left(\mathrm{NO}_{3}\right)_{2}[23] \\
\operatorname{cis}-\left[\left(\mathrm{PPh}_{3}\right)_{2} \mathrm{Pt}\left\{\operatorname{ado}(-\mathrm{H}), N^{6} N^{7}\right\}\right] \mathrm{NO}_{3} \mathbf{4} \\
\operatorname{cis}-\left[\left(\mathrm{PPh}_{3}\right)_{2} \mathrm{Pt}\left\{9-\mathrm{MeAd}(-\mathrm{H}), N^{6} N^{7}\right\}\right] \mathrm{NO}_{3}[26]\end{array}$ & $\begin{array}{r}-30.33(3004) \\
8.74(3874) \\
9.20(3850)\end{array}$ & $\begin{array}{r}-30.98(3236) \\
5.64(3131) \\
5.57(3162)\end{array}$ & $\begin{array}{l}26.1 \\
19.9 \\
20.0\end{array}$ & $\begin{array}{l}8.11 \\
8.05 \\
8.03\end{array}$ & $\begin{array}{l}8.02 \\
6.76 \\
6.62\end{array}$ & $\begin{array}{l}6.58 \\
5.20 \\
4.51\end{array}$ \\
\hline
\end{tabular}


whereas the binding mode of the nucleoside was established by ${ }^{15} \mathrm{~N}-{ }^{1} \mathrm{H}$ and ${ }^{31} \mathrm{P}-{ }^{1} \mathrm{H}$ HMBC experiments in $\mathrm{CDCl}_{3}$ (Figs. 1 and 2 ).

The proton resonances at $\delta 5.43$ and $5.83 \mathrm{ppm}$, attributable to the $\mathrm{H}^{\prime}{ }^{\prime}$ and $\mathrm{H} 8$ adenosine protons, respectively, correlate with the ${ }^{15} \mathrm{~N}$ nucleus at $\delta-200.0 \mathrm{ppm}$, assigned to $\mathrm{N}(9)$. The $\mathrm{H} 8$ proton further correlates also with $\mathrm{N}(7)$ at $\delta-191.4 \mathrm{ppm}$. The proton resonance at $\delta 8.13 \mathrm{ppm}$, assigned to $\mathrm{H} 2$, correlates with the ${ }^{15} \mathrm{~N}$ resonances at $\delta-160.9$ (N1) and at $-135.2 \mathrm{ppm} \mathrm{N}(3)$. Finally, the N(6)H proton at $\delta 4.64 \mathrm{ppm}$ (Figure S2 Supplementary Material) correlates with $\mathrm{N}(6)$ at $\delta-242.1 \mathrm{ppm}$ and exhibits the expected couplings ${ }^{1} J_{\mathrm{NH}}=84$ and ${ }^{2} J_{\mathrm{NP}}=88 \mathrm{~Hz}$.

The ${ }^{31} \mathrm{P}$ NMR spectrum exhibits an AB multiplet, with sharp ${ }^{195} \mathrm{Pt}$ satellites, at $\delta 8.26\left({ }^{1} J_{\mathrm{PPt}}=3846 \mathrm{~Hz}\right)$ and $6.58\left({ }^{1} J_{\mathrm{PPt}}=3124 \mathrm{~Hz}\right)$. As shown in Fig. 2, the first resonance correlates with the adenine H8 proton at $\delta 5.83$ and both of them show correlation with the $\mathrm{N}(6) \mathrm{H}$ proton at $\delta 4.64$ (partially overlapped with the ribose $\mathrm{H} 2$ ' multiplet, at $300 \mathrm{MHz}$ ). These results led to the conclusion that the nucleoside is chelated to the metal through the N6 and N7 atoms, as previously found for the nucleobase 9-methyadenine [26]. Selected ${ }^{31} \mathrm{P}$ and ${ }^{1} \mathrm{H}$ NMR data of the nucleosides and the corresponding model nucleobase are collected in Table 1 . It is noteworthy that the replacement of the methyl group with the ribose does not change significantly the spectroscopic parameters of these nucleobase/nucleoside adducts.

As anticipated, adenosine reacts with cis- $\left[\left(\mathrm{PMe}_{3}\right)_{2} \mathrm{Pt}(\mu-\mathrm{OH})\right]_{2}$ $\left(\mathrm{NO}_{3}\right)_{2}$, to give the dinuclear species cis-[(PMe $)_{2} \mathrm{Pt}\{\mu$-ado $(-\mathrm{H})$, $\left.\left.N^{1} N^{6}\right\}\right]_{2}\left(\mathrm{NO}_{3}\right)_{2}$, 3, that has been isolated as a pure compound performing the condensation reaction in water (see Section 2). The coordination mode of the nucleoside was established by comparison of the multinuclear NMR data with those of the nucleobase analog cis$\left[\left(\mathrm{PMe}_{3}\right)_{2} \mathrm{Pt}\left\{\mu-9-\operatorname{MeAd}(-\mathrm{H}), N^{1} N^{6}\right\}\right]_{2}\left(\mathrm{NO}_{3}\right)_{2}$ [23], (Table 1) and cis$\left[\left(\mathrm{PMe}_{3}\right)_{2} \mathrm{Pt}\left\{\mu-9-\operatorname{EtAd}(-\mathrm{H}), N^{1} N^{6}\right\}\right]_{2}\left(\mathrm{NO}_{3}\right)_{2}$ [27]. For this last adduct the N1,N6-coordination of the nucleobase was confirmed by X-ray analysis [27]. The dinuclear species for $\mathbf{3}$ is characterized by the presence of two $\mathrm{AB}$ multiplets in the ${ }^{31} \mathrm{P}$ NMR spectrum, as well as of distinct resonances for the nucleobase $\mathrm{H} 2, \mathrm{H} 8$ and $\mathrm{N}(6) \mathrm{H}$ protons (see Table 1), in line with the existence of two conformers resulting in the relative orientation, syn and anti, of the ribose groups with respect to the coordination plane of the metal.

The reaction, monitored $v i{ }^{31} \mathrm{P}$ NMR spectroscopy, in DMSO, leads initially to a mixture of products that slowly rearranges quantitatively into the thermodynamically stable species 3 . As an example, the ${ }^{31} \mathrm{P}$ NMR spectrum of the mixture containing cis- $\left[\left(\mathrm{PMe}_{3}\right)_{2} \mathrm{Pt}(\mu-\mathrm{OH})\right]_{2}$ $\left(\mathrm{NO}_{3}\right)_{2}$ and ado (molar ratio 1:2) in DMSO- $d_{6}$ is shown in Fig. 3.

The spectrum obtained immediately after the dissolution of the reagents shows still a small amount of the reacting hydroxo complex

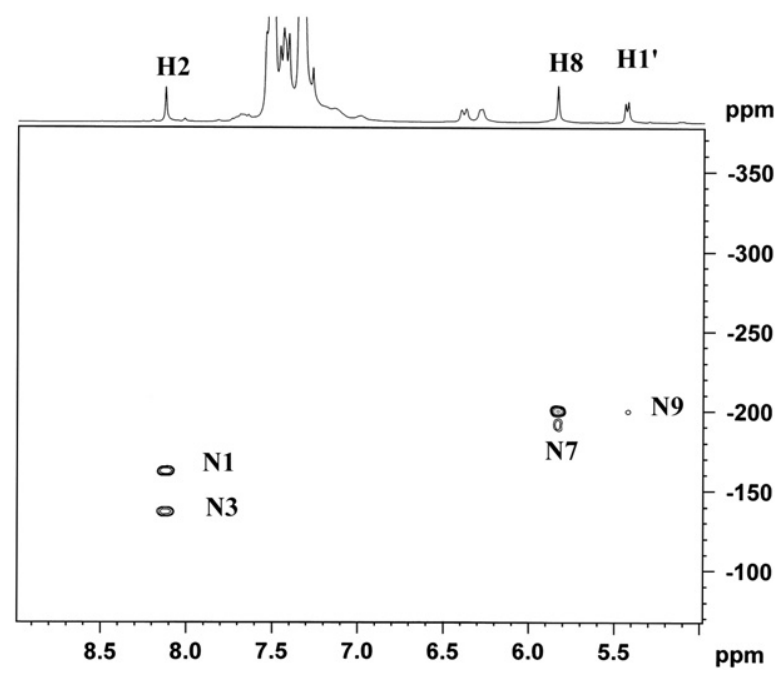

Fig. 1. ${ }^{15} \mathrm{~N}-{ }^{1} \mathrm{H}$ HMBC NMR experiment (long range, evolution time $55 \mathrm{~ms}$ ) in $\mathrm{CDCl}_{3}$ of the complex 4.

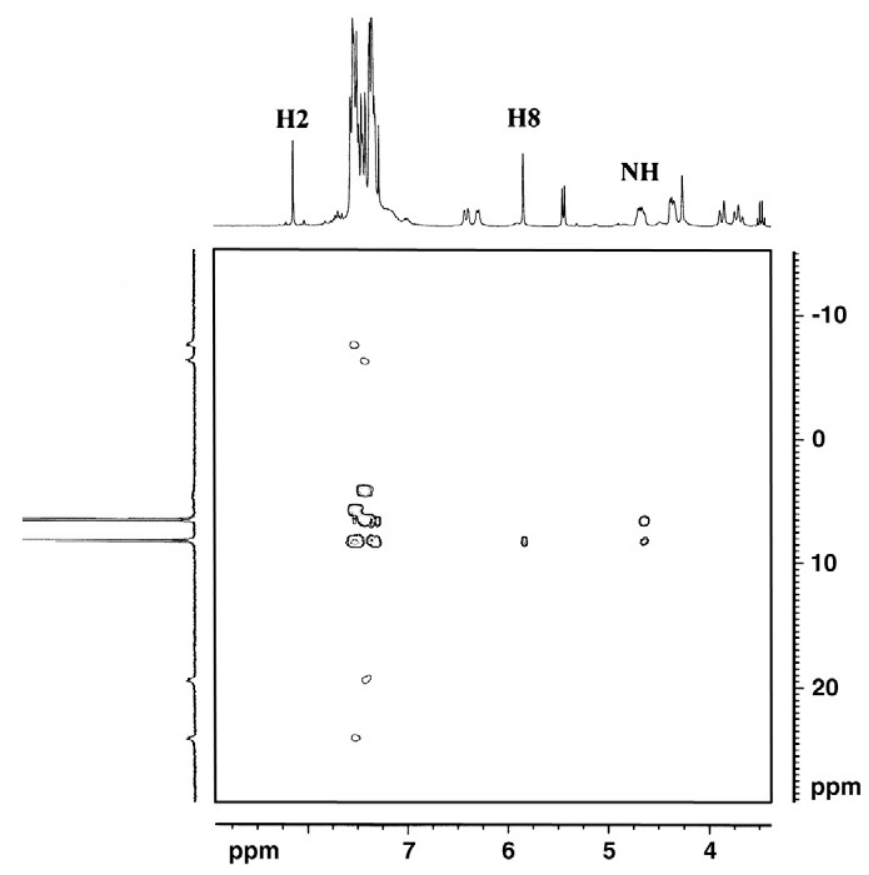

Fig. 2. ${ }^{31} \mathrm{P}-{ }^{1} \mathrm{H}$ HMBC NMR experiment in $\mathrm{CDCl}_{3}$ of the complex 4 .

(singlet at $\delta-23.9 \mathrm{ppm}$ ), in agreement with a relatively slow condensation reaction at ambient conditions. The main product (Fig. 3a) is characterized by an $\mathrm{AB}$ multiplet at $\delta-26.64\left({ }^{1} J_{\mathrm{PPt}}=3285 \mathrm{~Hz}\right)$ and $-28.13\left({ }^{1} J_{\mathrm{PPt}}=3111 \mathrm{~Hz} ;{ }^{2} J_{\mathrm{PP}}=25.2 \mathrm{~Hz}\right)$, tentatively attributed to mononuclear N6,N7-chelate analogous to 4 or its linkage isomer cis$\left[\left(\mathrm{PMe}_{3}\right)_{2} \mathrm{Pt}\left\{\operatorname{ado}(-\mathrm{H}), N^{1} N^{6}\right\}\right]\left(\mathrm{NO}_{3}\right)$. In a few days at $27^{\circ} \mathrm{C}$, these signals are completely replaced by two $\mathrm{AB}$ multiplets, having relative intensities ca. 45:55, at higher field (Fig. 3b), attributable to the isolated dinuclear species 3 . The spectrum does not change after 4 days at $75^{\circ} \mathrm{C}$, suggesting a high stability of the dimeric structure of this adduct.

\subsection{Syntheses of the amidine complexes}

When the reaction of cis- $\left[\left(\mathrm{PPh}_{3}\right)_{2} \mathrm{Pt}(\mu-\mathrm{OH})\right]_{2}\left(\mathrm{NO}_{3}\right)_{2}$ with the nucleosides cyt and ado is carried out in solution of nitriles $(\mathrm{RCN}, \mathrm{R}=\mathrm{Me}, \mathrm{Ph})$ the amidine derivatives cis- $\left[\left(\mathrm{PPh}_{3}\right)_{2} \mathrm{PtNH}=\mathrm{C}(\mathrm{R})\{\mathrm{cyt}(-2 \mathrm{H})\}\right] \mathrm{NO}_{3}$ $(\mathrm{R}=\mathrm{Me}, \mathbf{5} \mathbf{a} ; \mathrm{R}=\mathrm{Ph}, \mathbf{5 b})$ and $c i s-\left[\left(\mathrm{PPh}_{3}\right)_{2} \mathrm{PtNH}=\mathrm{C}(\mathrm{R})\{\operatorname{ado}(-2 \mathrm{H})\}\right] \mathrm{NO}_{3}$ $(\mathrm{R}=\mathrm{Me}, \mathbf{6} \mathbf{a}: \mathrm{R}=\mathrm{Ph}, \mathbf{6 b})$, depicted in Scheme 3, are formed.

The formal insertion of a nitrile molecule into a Pt-nitrogen bond of the cytidine that occurs at room temperature in a few hours, is
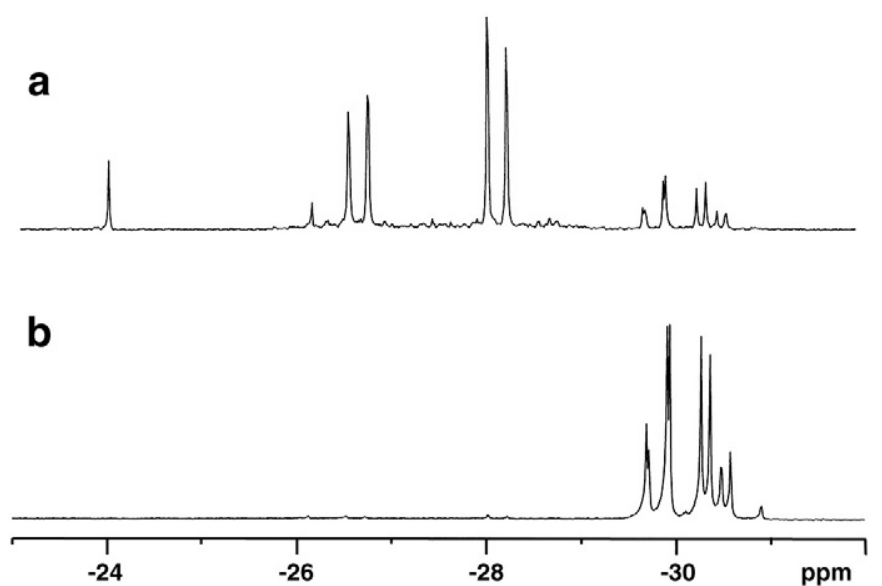

Fig. 3. $\left\{{ }^{1} \mathrm{H}\right\}^{31} \mathrm{P}$ NMR experiments of the mixture between cis- $\left[\left(\mathrm{PMe}_{3}\right)_{2} \mathrm{Pt}(\mu-\mathrm{OH})\right]_{2}$ $\left(\mathrm{NO}_{3}\right)_{2}$ and adenosine (1:2) in DMSO- $d_{6}$. a) immediately after the dissolution; b) after 4 days at $27^{\circ} \mathrm{C}$. 


\section{cytidine}

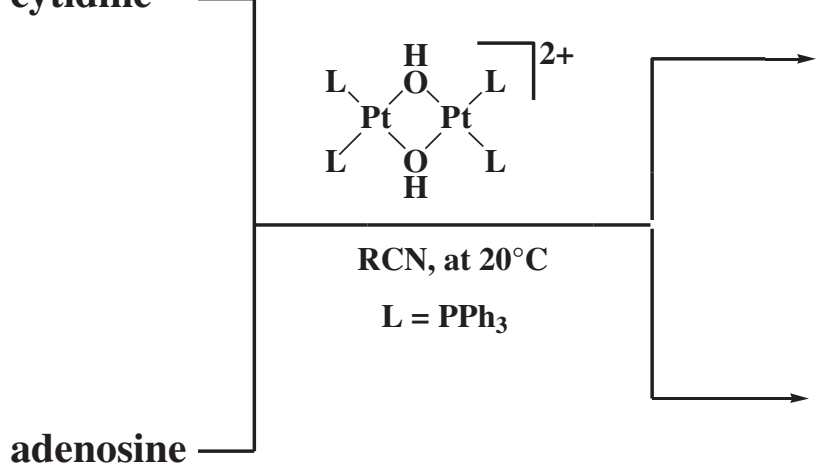<smiles>[R]C1=N[Y]([H])([3H])N2C(=O)N([R17])C=CC2=N1</smiles>

5a: $\mathbf{R}=\mathbf{M e}$

5b: $\mathbf{R}=\mathbf{P h}$

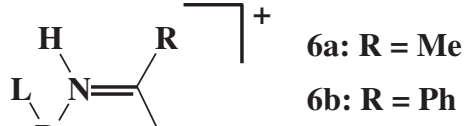

Scheme 3. Pathway reaction for amidine complexes $\mathbf{5 a , b}$ and $\mathbf{6 a} \mathbf{\mathbf { a }} \mathbf{b}$.

quantitative (by ${ }^{31} \mathrm{P}$ NMR) and no intermediates are detectable. On the contrary, in the case of adenosine the initial product is the nucleoside adduct $\mathbf{4}$, which slowly reacts with the solvent to give the amidines $\mathbf{6 a}, \mathbf{b}$.

The products have been isolated, in good yield, as pale yellow solids and characterized by elemental analysis and NMR spectroscopy in $\mathrm{CDCl}_{3}$. The ${ }^{1} \mathrm{H}$ and ${ }^{31} \mathrm{P}$ NMR data are very similar to those exhibited by the nucleobase analogs $[20,21]$, cis- $\left[\left(\mathrm{PPh}_{3}\right)_{2} \mathrm{PtNH}=\mathrm{C}(\mathrm{R})\{1-\mathrm{MeCy}\right.$ $(-2 \mathrm{H})\}] \mathrm{NO}_{3}(\mathrm{R}=\mathrm{Me}, \mathbf{7 a}: \mathrm{R}=\mathrm{Ph}, \mathbf{7 b})$, cis-[(PPh$)_{2} \mathrm{PtNH}=\mathrm{C}(\mathrm{R})\{9-$ $\operatorname{MeAd}(-2 \mathrm{H})\}] \mathrm{NO}_{3}(\mathrm{R}=\mathrm{Me}, \mathbf{8} \mathbf{a}: \mathrm{R}=\mathrm{Ph}, \mathbf{8 b})$ previously characterized. In Table 2 selected ${ }^{31} \mathrm{P}$ and ${ }^{1} \mathrm{H}$ NMR of these complexes are collected.

Unlike complexes 1-3, the amidine derivatives $\mathbf{6}$ and $\mathbf{7}$ show a single set of resonances in the ${ }^{31} \mathrm{P}$ and ${ }^{1} \mathrm{H}$ spectra, suggesting a preferred orientation of the ribose group with respect to the nucleobase ring (single conformation) or a fast rotation around the glycosidic bond.

In solution, complexes $\mathbf{5 a}$ and $\mathbf{6} \mathbf{a}$ are indefinitely stable only in $\mathrm{CH}_{3} \mathrm{CN}$. In chlorinated solvents (or DMSO) 5a slowly releases $\mathrm{CH}_{3} \mathrm{CN}$ and forms reversibly a complex mixture of uncharacterized products while $\mathbf{6 a}$ forms 4.

The analogous complexes with benzonitrile are stable in PhCN as well as in solution of DMSO or chlorinated solvents.

\subsection{Cytotoxicity tests}

Pt(II) nucleosides (1-4) as well as the corresponding Pt(II) benzamidine nucleosides $(\mathbf{5 b}, \mathbf{6 b})$ and acetamidine $(\mathbf{7 a}, \mathbf{8 a})$ or benzami- damide (7b, 8b) nucleobase derivatives were evaluated for their cytotoxic activity towards a panel of 8 human tumor cell lines including examples of ovarian (2008 and C13*), cervical (A431 and A4317Pt), colon (LoVo and LoVo MDR) and breast (MCF-7) cancer and melanoma (A375). Acetamidine Pt(II) nucleosides (5a, 6a) were not tested for their cytotoxicity owing to their poor stability in DMSO. Cytotoxicity was evaluated by means of MTT tests after $72 \mathrm{~h}$ of treatment with increasing concentrations of the tested compounds. For comparison purposes, the cytotoxicity of cisplatin, the most widely used anticancer metallodrug, was evaluated in the same experimental conditions. $\mathrm{IC}_{50}$ values, calculated from dose-survival curves, are shown in Table 3.

$\mathrm{Pt}(\mathrm{II})$ nucleosides (1-4) proved to be completely ineffective over 8 cell lines; the negligible activity shown by $\mathbf{1 - 4}$ could be associated with the high kinetic inertness of these molecules as assessed by mass and NMR studies. Among Pt(II) amidine nucleoside and nucleobase complexes, cytosine derivatives proved to be much more effective than those containing adenine. In particular, adenosine and adenine derivatives $\mathbf{6 b}, \mathbf{8 a}$ and $\mathbf{8 b}$ showed mean $\mathrm{IC}_{50}(\mu \mathrm{M})$ values of 24.87 (34.24-12.41), 21.68 (24.91-16.34) and 20.55 (24.73-10.47), respectively, which were about four times higher than that of cisplatin $(5.45 \mu \mathrm{M})$. Among Pt(II) cytidine and cytosine complexes, acetamidine nucleobase 7a showed the worst cytotoxic potency, eliciting a cancer cell growth inhibition roughly 2.5 times lower than cisplatin. Conversely, Pt(II) benzamidine nucleobase $\mathbf{7 b}$ distinguished itself as the most promising derivative, being able to decrease cell viability

Table 2

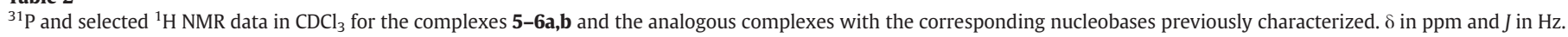

\begin{tabular}{|c|c|c|c|c|c|c|}
\hline Complex & $\mathrm{P}_{\mathrm{A}}\left({ }^{1} J_{\mathrm{PPt}}\right)$ & $\mathrm{P}_{\mathrm{B}}\left({ }^{1} J_{\mathrm{PPt}}\right)$ & ${ }^{2} J_{\mathrm{PP}}$ & $\mathrm{H} 2 / \mathrm{H} 5$ & $\mathrm{H} 8 / \mathrm{H} 6$ & $\mathrm{NH}$ \\
\hline $\operatorname{cis}-\left[\left(\mathrm{PPh}_{3}\right)_{2} \mathrm{PtHN}=\mathrm{C}(\mathrm{Me})\{\operatorname{cyt}(-2 \mathrm{H})\}\right] \mathrm{NO}_{3} \mathbf{5 a}$ & $8.47(3468)$ & $7.92(3432)$ & 25.0 & 6.00 & 7.95 & 5.50 \\
\hline $\operatorname{cis}-\left[\left(\mathrm{PPh}_{3}\right)_{2} \mathrm{PtHN}=\mathrm{C}(\mathrm{Ph})\{\operatorname{cyt}(-2 \mathrm{H})\}\right] \mathrm{NO}_{3} \mathbf{5 b}$ & $8.50(3485)$ & $7.86(3450)$ & 24.8 & 6.24 & 7.98 & 6.00 \\
\hline $\operatorname{cis}-\left[\left(\mathrm{PPh}_{3}\right)_{2} \mathrm{PtHN}=\mathrm{C}(\mathrm{Me})\{\operatorname{ado}(-2 \mathrm{H})\}\right] \mathrm{NO}_{3} \mathbf{6 a}$ & $11.10(3220)$ & $10.71(3417)$ & 23.8 & 8.02 & a & 6.35 \\
\hline $\operatorname{cis}-\left[\left(\mathrm{PPh}_{3}\right)_{2} \mathrm{PtHN}=\mathrm{C}(\mathrm{Ph})\{\operatorname{ado}(-2 \mathrm{H})\}\right] \mathrm{NO}_{3} \mathbf{6 b}$ & $11.30(3256)$ & $10.14(3399)$ & 24.3 & 8.06 & a & 6.24 \\
\hline $\operatorname{cis}-\left[\left(\mathrm{PPh}_{3}\right)_{2} \mathrm{PtHN}=\mathrm{C}(\mathrm{Me})\{1-\mathrm{MeCy}(-2 \mathrm{H})\}\right] \mathrm{NO}_{3} \mathbf{7 a}$ & $8.99(3477)$ & 7.77 (3419) & 24.8 & 6.02 & 7.20 & 5.72 \\
\hline cis- $\left[\left(\mathrm{PPh}_{3}\right)_{2} \mathrm{PtHN}=\mathrm{C}(\mathrm{Ph})\{1-\mathrm{MeCy}(-2 \mathrm{H})\}\right] \mathrm{NO}_{3} \mathbf{7 b}$ & $9.03(3486)$ & 7.77 (3417) & 24.9 & 6.22 & 7.14 & 6.05 \\
\hline cis- $\left[\left(\mathrm{PPh}_{3}\right)_{2} \mathrm{PtHN}=\mathrm{C}(\mathrm{Me})\{9-\mathrm{MeAd}(-2 \mathrm{H})\}\right] \mathrm{NO}_{3} \mathbf{8 a}$ & $11.33(3385)$ & $10.86(3369)$ & 24.7 & 8.11 & 7.81 & 5.44 \\
\hline cis- $\left[\left(\mathrm{PPh}_{3}\right)_{2} \mathrm{PtHN}=\mathrm{C}(\mathrm{Ph})\{9-\mathrm{MeAd}(-2 \mathrm{H})\}\right] \mathrm{NO}_{3} \mathbf{8 b}$ & $10.95(3263)$ & $10.70(3370)$ & 24.5 & 8.28 & 7.95 & 6.32 \\
\hline
\end{tabular}

\footnotetext{
a Overlapped with the $\mathrm{PPh}_{3}$ signals.
} 
Table 3

Cytotoxicity.

\begin{tabular}{|c|c|c|c|c|c|c|c|c|c|c|c|}
\hline \multirow[t]{2}{*}{ Compound } & \multicolumn{11}{|c|}{$\mathrm{IC}_{50}(\mu \mathrm{M}) \pm$ S.D. } \\
\hline & A375 & MCF-7 & A431 & $\mathrm{A} 431 / \mathrm{Pt}$ & R.F. & 2008 & C13 & R.F. & LoVo & LoVo MDR & R.F. \\
\hline $\begin{array}{l}\text { cis- }\left[\left(\mathrm{PMe}_{3}\right)_{2} \mathrm{Pt}\{\operatorname{cyt}(-\mathrm{H})\right. \\
\left.\left.\mathrm{N}^{3} \mathrm{~N}^{4}\right\}\right]_{3}\left(\mathrm{NO}_{3}\right)_{3} \mathbf{1}\end{array}$ & $>100$ & $>100$ & $>100$ & $>100$ & - & $>100$ & $>100$ & - & $>100$ & $>100$ & - \\
\hline $\begin{array}{l}\text { cis- }\left[\left(\mathrm{PMe}_{3}\right)_{2} \mathrm{Pt}\{\operatorname{ado}(-\mathrm{H})\right. \\
\left.\left.\quad N^{1} N^{6}\right\}\right]_{2}\left(\mathrm{NO}_{3}\right)_{2} 3\end{array}$ & $>100$ & $>100$ & $>100$ & $>100$ & - & $>100$ & $>100$ & - & $>100$ & $>100$ & - \\
\hline $\begin{array}{l}\text { cis- }\left[\left(\mathrm{PPh}_{3}\right)_{2} \mathrm{Pt}\{\operatorname{ado}(-\mathrm{H})\right. \\
\left.\left.\left.\mathrm{N}^{6} \mathrm{~N}^{7}\right\}\right] \mathrm{NO}_{3}\right) \mathbf{4}\end{array}$ & $>100$ & $>100$ & $>100$ & $>100$ & - & $>100$ & $>100$ & - & $>100$ & $>100$ & - \\
\hline $\begin{array}{c}\text { cis- }\left[\left(\mathrm{PPh}_{3}\right)_{2} \mathrm{PtNH}=\mathrm{C}(\mathrm{Ph})\right. \\
\{\operatorname{cyt}(-2 \mathrm{H})\}] \mathrm{NO}_{3} \mathbf{5 b}\end{array}$ & $2.44 \pm 1.13$ & $7.55 \pm 1.94$ & $3.98 \pm 0.69$ & $3.13 \pm 2.03$ & 1.0 & $4.77 \pm 1.43$ & $10.32 \pm 1.04$ & 0.8 & $7.34 \pm 1.15$ & $8.56 \pm 1.47$ & 1.1 \\
\hline $\begin{array}{c}\text { cis }-\left[\left(\mathrm{PPh}_{3}\right)_{2} \mathrm{PtNH}=\mathrm{C}(\mathrm{Ph})\right. \\
\{\operatorname{ado}(-2 \mathrm{H})\}] \mathrm{NO}_{3} \mathbf{6 b}\end{array}$ & $29.83 \pm 1.53$ & $31.58 \pm 1.41$ & $23.12 \pm 1.35$ & $18.48 \pm 1.21$ & 0.8 & $12.41 \pm 1.45$ & $20.37 \pm 1.85$ & 1.8 & $28.92 \pm 1.25$ & $34.24 \pm 2.14$ & 1.4 \\
\hline $\begin{array}{l}\text { cis- }\left[\left(\mathrm{PPh}_{3}\right)_{2} \mathrm{PtNH}=\mathrm{C}(\mathrm{Me})\right. \\
\quad\{1-\mathrm{MeCy}(-2 \mathrm{H})\}] \mathrm{NO}_{3} \mathbf{7 a}\end{array}$ & $6.93 \pm 1.31$ & $24.14 \pm 2.25$ & $13.52 \pm 1.54$ & $11.66 \pm 1.12$ & 0.8 & $7.70 \pm 1.16$ & $12.64 \pm 1.90$ & 0.8 & $8.54 \pm 2.11$ & $13.24 \pm 2.24$ & 1.3 \\
\hline $\begin{array}{l}\text { cis- }\left[\left(\mathrm{PPh}_{3}\right)_{2} \mathrm{PtNH}=\mathrm{C}(\mathrm{Ph})\right. \\
\quad\{1-\mathrm{MeCy}(-2 \mathrm{H})\}] \mathrm{NO}_{3} \mathbf{7 b}\end{array}$ & $2.27 \pm 1.00$ & $4.58 \pm 1.13$ & $2.87 \pm 0.79$ & $2.48 \pm 1.01$ & 0.8 & $3.47 \pm 1.02$ & $3.36 \pm 1.12$ & 0.9 & $2.89 \pm 1.25$ & $3.85 \pm 1.36$ & 1.3 \\
\hline $\begin{array}{l}\text { cis- }\left[\left(\mathrm{PPh}_{3}\right)_{2} \mathrm{PtNH}=\mathrm{C}(\mathrm{Me})\right. \\
\quad\{9-\operatorname{MeAd}(-2 \mathrm{H})\}] \mathrm{NO}_{3} \mathbf{8 a}\end{array}$ & $16.34 \pm 1.00$ & $24.67 \pm 1.90$ & $22.11 \pm 0.94$ & $24.91 \pm 1.43$ & 1.1 & $20.23 \pm 3.01$ & $24.41 \pm 1.98$ & 1.2 & $19.54 \pm 1.38$ & $21.25 \pm 2.55$ & 1.3 \\
\hline $\begin{array}{l}\text { cis }-\left[\left(\mathrm{PPh}_{3}\right)_{2} \mathrm{PtNH}=\mathrm{C}(\mathrm{Ph})\right. \\
\quad\{9-\operatorname{MeAd}(-2 \mathrm{H})\}] \mathrm{NO}_{3} \mathbf{8 b}\end{array}$ & $19.11 \pm 1.75$ & $31.15 \pm 2.62$ & $23.47 \pm 1.28$ & $18.49 \pm 1.77$ & 0.7 & $23.89 \pm 1.63$ & $24.73 \pm 2.17$ & 1.1 & $10.47 \pm 1.28$ & $13.13 \pm 1.96$ & 1.3 \\
\hline Cisplatin & $2.47 \pm 1.23$ & $9.01 \pm 1.54$ & $1.89 \pm 1.67$ & $5.81 \pm 1.33$ & 3.1 & $3.75 \pm 1.86$ & $32.13 \pm 1.76$ & 8.6 & $7.89 \pm 3.02$ & $7.31 \pm 2.21$ & 1.0 \\
\hline
\end{tabular}

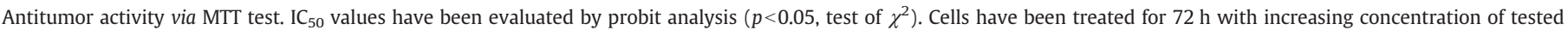
compounds. Resistant factor (RF) is defined as $\mathrm{IC}_{50}$ resistant/parent line. S.D.: standard deviation.

about 2 times more effectively than cisplatin (average $\mathrm{IC}_{50}$ of $3.22 \mu \mathrm{M}$ and $5.45 \mu \mathrm{M}$ for $\mathbf{7 b}$ and cisplatin, respectively). Pt(II) benzamidine nucleoside $\mathbf{5 b}$, despite retaining an antiproliferative activity slightly lower than that of the relative $\mathrm{Pt}(\mathrm{II})$ nucleobase complexes $\mathbf{7 a}$ and $\mathbf{7 b}$ (average $\mathrm{IC}_{50}$ of 3.22 and $6.01 \mu \mathrm{M}$ for $\mathbf{7 b}$ and $\mathbf{7 a}$, respectively), has been found to possess a cytotoxic potency quite similar to that of the reference metallodrug. Among nucleobase amidine Pt(II) complexes, benzamidine derivatives proved to be more effective with respect to acetamidine analogs. This behavior may be related to the more lipophilic properties of the phenyl ring that could favor the crossing of the cell membrane. These data are in line with the results previously reported concerning trans-Pt(II) amidine complexes [28,29].

The in-house panel also included two cell lines that have been selected for their resistance to cisplatin (human ovarian adenocarcinoma C13* cells, human cervical carcinoma A431/Pt cells). Although cisplatin resistance is multifactorial, the main molecular mechanisms involved in Pt resistance of C13* and A431/Pt have been identified. In particular, in $\mathrm{C}_{13}{ }^{*}$ cells' resistance is correlated to reduced cellular drug uptake, high cellular glutathione and thioredoxin reductase levels and enhanced repair of DNA damage [30,31]. In A431/Pt cells, resistance is due to a defect in drug uptake and to decreased levels of proteins involved in DNA mismatch repair (MSH2), which causes an increased tolerance to cisplatin-induced DNA damage [32]. By comparing the RF values (where RF is the resistance factor and is defined as the ratio between $\mathrm{IC}_{50}$ values calculated for the resistant cells and those arising from the sensitive ones), new $\mathrm{Pt}$ (II) amidine nucleoside and nucleobase complexes were found to be able to overcome cisplatin resistance. The resistance factors calculated for these derivatives were about 8 and 3 times lower than that of cisplatin on the 2008-C13* and A431-A431/Pt cell pairs, respectively.

Additionally, $\mathrm{Pt}(\mathrm{II})$ amidine complexes were tested against a multidrug resistant (MDR) colon carcinoma subline, LoVo MDR cells. It is well known that acquired MDR, whereby cells become refractory to multiple drugs, poses a most important challenge to the success of anticancer chemotherapy. The resistance of LoVo MDR cells to doxorubicin, a drug belonging to the MDR spectrum, is associated with an overexpression of the multi-specific drug transporters, such as, for example, the $170 \mathrm{kDa}$ P-glycoprotein (P-gp) [33]. Although cisplatin is not a P-glycoprotein substrate; many multidrug resistance protein (MRP1, MRP2, MRP4) have been found involved in platinum complex transport and are responsible for its efflux/afflux from the cell [34-36]. Cytotoxicity assays testing Pt(II) amidine derivatives against this cell line pair showed a similar pattern of response across the parental and the resistant subline thus suggesting that these new $\mathrm{Pt}(\mathrm{II})$ complexes are not potential MDR substrates.

\section{Conclusions}

The main results of this study can be summarized as follows: a) the substitution of the methyl group in the model nucleobase 1-MeCy and 9-MeAd with the ribose group does not change significantly the reactivity pattern of these biomolecules toward the hydroxo complex cis- $\left[\mathrm{L}_{2} \mathrm{Pt}(\mu-\mathrm{OH})\right]_{2}^{2+}$. The less hindered phosphines stabilize polynuclear adducts in which the deprotonated nucleoside acts as bridging ligand. The di- and/or trimerization of the nucleoside adducts is prevented when the hydroxo reagent is stabilized by $\mathrm{PPh}_{3}$. b) A similar effect of the phosphine ligands is observed in the activation of nitriles: the insertion of a molecule of $\mathrm{CH}_{3} \mathrm{CN}$ or PhCN occurs only with the less basic $\mathrm{PPh}_{3}$. c) Among the isolated complexes, only the amidine derivatives exhibit a clear cytotoxic activity toward different human tumor cell lines. In particular, the benzamidine cis- $\left[\left(\mathrm{PPh}_{3}\right)_{2-}\right.$ $\mathrm{PtHN}=\mathrm{C}(\mathrm{Ph})\{1-\mathrm{MeCy}(-2 \mathrm{H})\}] \mathrm{NO}_{3}(\mathbf{7 b})$ shows interesting properties, in terms of antiproliferative effects, even toward $\mathrm{C} 13^{*}$ cisplatin resistant cells and this important finding could be due to a different mechanism of action with respect to the reference metallodrug.

\section{Acknowledgements}

This work was financially supported by University of Padua and by Ministero dell'Istruzione dell'Università e della Ricerca. We are grateful to CIRCMSB (Consorzio Interuniversitario di Ricerca in Chimica dei Metalli nei Sistemi Biologici).

\section{Appendix A. Supplementary data}

Supplementary data to this article can be found online at doi:10.1016/j.jinorgbio.2011.03.009.

\section{References}

[1] B. Lippert, Coord. Chem. Rev. 200-202 (2000) 487-516.

[2] E. Zangrando, F. Pichierri, L. Randaccio, B. Lippert, Coord. Chem. Rev. 156 (1996) 275-332.

[3] B. Lippert, Prog. Inorg. Chem. 54 (2005) 385-447.

[4] B. Rosemberg, L. Van Camp, J.E. Trosko, V.H. Mansour, Nature 222 (1969) 385-386. 
[5] B. Rosemberg, L. Van Camp, T. Krigas, Nature 205 (1965) 698-699.

[6] B. Rosemberg, in: B. Lippert (Ed.), Cisplatin: Chemistry and Biochemistry of a Leading anticancer Drug, Wiley-VHC, Zurich, 1999, pp. 3-27.

[7] D.S. Alberts, in: H.M. Pinedo, J.H. Schornagel (Eds.), Platinum and other Metal Coordination Compounds in Cancer Chemotherapy 2, Plenum Press, New York and London, 1996, pp. 303-310.

[8] T. Ishibashi, Y. Yano, T. Oguma, Cancer Chemother. Pharmacol. 50 (2002) 230-236.

[9] E. Raymond, S.G. Chaney, A. Taama, E. Cvitkovic, Ann. Oncol. 9 (1998) 1053-1071.

[10] M.D. Hall, T.W. Hambley, Coord. Chem. Rev. 232 (2002) 49-67.

[11] M.S. Ali, S.R.A. Khan, H. Ojima, I.Y. Guzman, K.H. Whitmire, Z.H. Siddik, A.R. Khokhar, J. Inorg. Biochem. 99 (2005) 795-804.

[12] W.Z. Shen, B. Lippert, J. Inorg. Biochem. 102 (2008) 1134-1140.

[13] Y. Suzuky, M. Tanokura, T. Shimizu, Eur. J. Biochem. 257 (1998) 466-471.

[14] K. Yamanari, R. Yto, S. Yamamoto, T. Konno, A. Fuyuhiro, M. Kobayashi, R. Arakawa, Dalton Trans. (2003) 380-386.

[15] A. Messere, E. Fabbri, M. Borgatti, R. Gambari, B. Di Blasio, C. Pedone, A. Romanelli, J. Inorg. Biochem. 101 (2007) 254-260.

[16] J. Arpalahti, K.D. Klika, R. Sillanpää, R. Kivekäs, J. Chem. Soc. Dalton Trans. (1998) 1397-1402.

[17] M. Mikola, K.D. Klika, R. Sillanpää, J. Arpalahti, Chem. Eur. J. 6 (2000) 3404-3413.

[18] L. Schenetti, G. Bandoli, A. Dolmella, G. Trovò, B. Longato, Inorg. Chem. 33 (1994) 3169-3176.

[19] B. Longato, D. Montagner, E. Zangrando, Inorg. Chem. 45 (2006) 8179-8187.

[20] B. Longato, D. Montagner, G. Bandoli, E. Zangrando, Inorg. Chem. 45 (2006) 1805-1814.

[21] D. Montagner, A. Venzo, E. Zangrando, B. Longato, Inorg. Chem. 49 (2010) 2103-2110.
[22] G. Trovò, G. Bandoli, U. Casellato, B. Corain, M. Nicolini, B. Longato, Inorg. Chem. 29 (1990) 4616-4621.

[23] L. Schenetti, A. Mucci, B. Longato, J. Chem. Soc. Dalton Trans. (1996) 299-303.

[24] D.T. Vistica, P. Skehan, D.A. Scudiero, A. Monks, A. Pittman, M.R. Boyd, Cancer Res. 51 (1991) 2515-2520.

[25] M.C. Alley, D.A. Scudiero, A. Monks, M.L. Hursey, M.J. Czerwinski, D.L. Fine, B.J. Abbott, J.G. Mayo, R.H. Shoemaker, M.R. Boyd, Cancer Res. 48 (1988) 589-601.

[26] D. Montagner, B. Longato, Inorg. Chim. Acta 361 (2008) 1676-1680.

[27] G. Trovò, G. Bandoli, M. Nicolini, B. Longato, Inorg. Chim. Acta 211 (1993) 95-99.

[28] F.P. Intini, R.Z. Pellicani, A. Boccarelli, R. Sasanelli, M. Coluccia, G. Natile, Eur. J Inorg. Chem. (2008) 4555-4561.

[29] S. Mazzega Sbovata, F. Bettio, C. Marzano, M. Mozzon, R. Bertani, F. Benetollo, R.A Michelin, Inorg. Chim. Acta 361 (2008) 3109-3116.

[30] D.P. Gately, S.B. Howell, Br. J. Cancer 67 (1993) 1171-1176.

31] C. Marzano, V. Gandin, A. Folda, G. Scutari, A. Bindoli, M.P. Rigobello, Free Rad. Bio. Med. 42 (2007) 872-881.

[32] C. Lanzi, P. Perego, R. Supino, S. Romanelli, T. Pensa, N. Carenini, I. Viano, D. Colangelo, R. Leone, P. Apostoli, G. Cassinelli, R.A. Gambetta, F. Zunino, Biochem. Pharmacol. 55 (1998) 1247-1254.

[33] C. Wersinger, G. Rebel, I.H. Lelong-Rebel, Amino Acids 19 (2000) 667-685.

[34] Y. Zhou, X.L. Ling, S.W. Li, X.Q. Li, B. Yan, World J. Gastroenterol. 16 (2010) $2291-2297$.

[35] S. Kamazawa, J. Kigawa, Y. Kanamori, H. Itamochi, S. Sato, T. Iba, N. Terakawa Gynecol. Oncol. 86 (2002) 171-176.

[36] Y.H. Zhang, Q. Wu, X.Y. Xiao, D.W. Li, X.P. Wang, Cancer Lett. 291 (2010) 76-82. 